\title{
Geophysical and geochemical alteration of rocks in granitic profiles during intense weathering in southern Purulia district, West Bengal, India
}

\author{
Gour Dolui $^{1}$ (1) $\cdot$ Soumendu Chatterjee $^{2} \cdot$ Nilanjana Das Chatterjee $^{1}$
}

Received: 29 June 2016/Accepted: 4 July 2016/Published online: 19 July 2016

(C) Springer International Publishing Switzerland 2016

\begin{abstract}
Purulia district of West Bengal is geologically dominated mostly by Proterozic hard granite gneiss rocks including soft phyllite and mica schist of Singhbhum group as part of Chotanagpur plateau. Present study aims to understand the nature of geophysical and geochemical weathering processes for characterization of granitic crust as well as the geochemical ways of this alteration. During the field study 14 rocks and soils samples were collected from three sections of each weathering profile in three different blocks namely, Manbazar-I, Manbazar-II and Banduan. The samples were collected along the roads cuts, natural and other man-made exposures and restricted mostly within the exposed layers of the respective profiles. The samples were analyses in sieve for particle size distribution and in X-ray diffraction for mineralogical alteration. The thin section of selected samples were analysed under polarized optical microscope for understanding the nature of physical and chemical changes in parent rocks. From sieve analysis, the cumulative particle size
\end{abstract}

Electronic supplementary material The online version of this article (doi:10.1007/s40808-016-0188-5) contains supplementary material, which is available to authorized users.

Gour Dolui

gourdolui@gmail.com

Soumendu Chatterjee

soumendu.geog@presiuniv.ac.in

Nilanjana Das Chatterjee

nilanjana_vu@mail.vidyasagar.ac.in

1 Department of Geography and Environment Management, Vidyasagar University, Midnapore 721102, West Bengal, India

2 Department of Geography, Presidency University, Kolkata, India distribution show that the size of weathered materials gradually reduces from saprolite to overlying soils in every profile. Mineralogical analysis by XRD shows that feldspar, muscovite, quartz and biotite are the primary minerals which are intensely weathered and have undergone some geochemical processes except quartz, to form some secondary clay minerals like montmorillonite, kaolinite and illite in the overlying soil. Optical microscopic analysis reveals that transformation of primary minerals to secondary clay minerals significantly reduced the rocks strength which leads the rocks disintegrate into smaller particles. Finally, the results show that there is an abundance of montmorillonite and altered primary minerals with gravel materials in the profiles are liable for further weathering to develop a mature soil.

Keywords Granite gneiss - Weathering - Sieve analysis . $\mathrm{X}$-ray diffraction $\cdot$ Clay minerals $\cdot$ Soil development

\section{Introduction}

Geophysical and geochemical pathways of rock modification have assumed academic interests in both geological and geomorphological studies. Weathering is an effective force of disintegration and decomposition for any kind of rock which is close to the Earth's surface (Atkinson 2004). Geochemical weathering and geophysical alterations occurs simultaneously while prompt physical disintegration of considered rocks and geochemical alteration of rock forming minerals, respectively to form regolith or soil and the resultant landscape is shaped accordingly (Atkinson 2004; Dolui et al. 2014). Weathering in any particular weathered profile is a combination of a set of geophysical and geochemical process responsible for alteration of parent rocks. 
Under the inference of prevailing controlling factors, the physical weathering processes disintegrate the parent rocks into smaller fragments of rock particles which are sensible for chemical attack. Therefore, chemical weathering changes the structure and chemical composition of parent rocks and thereby making the rocks more prone to physical disintegration which may leads to more mineral surface available for chemical weathering in turn. According to Gerrard (1988) some factors like rock types, surface topography, climatic condition and time are responsible for the variable nature of chemical weathering. At the same time physical weathering processes are also controlled by those factors as about chemical weathering. So, it is not possible to take any single weathering process for study in any particular weathering crust at the micro level.

Chemical weathering of rocks is one of the important processes that modify the earth's surface and one of the essential pathways in the geochemical cycling of elements (Berg 1932). Geophysical and geochemical weathering alters the physical, chemical or mineralogical properties of rocks. According to Mondensi (1983) both mechanical and chemical weathering processes are related to dynamics of geomorphology very closely as a driving force of morphogenesis. The complex interactions between the earth surface, climatic conditions, hydrology and ecology of any particular region shape the geomorphometry of the landscape. The oldest, and perhaps most susceptible theory in weathering studies emphasises on climatic control over the nature of rock fragmentation or physical weathering processes (Pope et al. 1995). But on micro scale, there are several denudational mechanisms and weathering processes to produced many distinctive landforms and resultant landscape where such kind of approaches may not be applied properly. Sometimes inductive approach is needed to establish some specific processes and their interactions which may not be fulfil at the smallest scale. However, recently researcher have reduced their scale of study to investigate complex weathering patterns because, in micro scale visual field study and laboratory based chemical analyses are more effective to understand the nature of weathering processes. Therefore, weathering is a key term for understanding about the weathering profiles, saprolite, regolith and soil formation (Turkington et al. 2005). Recently weathering studies focus on some key issues like process interactions, process landform relationship, time scale, modelling of weathering processes using empirical data etc. But the study of diversity of processes in rock weathering has gained significance as an important area of study in geomorphology.

Some studies has reported the pattern of physical and chemical/mineralogical alterations of different rock types of (igneous, sedimentary and metamorphic) under different climatic condition and thus, resultant landscape, as a geomorphological consequences vary widely (Le Pera and Sorriso-
Valvo 2000; Le Pera et al. 2000; Bouchard and Jolicoeur 2000; Calcaterra et al. 2004; Apollaro et al. 2007; Buccianti et al. 2009; Caracciolo et al. 2012; Perri et al. 2015). In case of granitic rocks in the Indian sub-continent some researchers investigate the chemical alteration and changing nature of physical properties of parent rocks due to weathering and their resultant end products. But this study first time represents a combined approach, of geophysical and geochemical weathering processes occurred on granitic weathering profiles and the processes of the formation of secondary minerals in the overlying soils. At the same time, this study represents the changing nature of distributional pattern of particle size in relation to alteration of mineralogical composition of parent rocks during intense weathering.

\section{Study area}

Purulia district; the area under present study, is located in the western most part of West Bengal (Fig. 1), as a part of eastern plateau of India. The Purulia district extends between $22^{\circ} 42^{\prime} 19^{\prime \prime} \mathrm{N}$ and $23^{\circ} 42^{\prime} 00^{\prime \prime} \mathrm{N}$ latitudes and $85^{\circ} 49^{\prime} 19^{\prime} \mathrm{E}$ and $86^{\circ} 54^{\prime} 25^{\prime \prime} \mathrm{E}$ longitudes covering an area of $6259 \mathrm{~km}^{2}$ and is surrounded by Paschim Medinipur, Bankura and Burdwan districts as part of West Bengal state and Dhanbad, Bokaro, Hazaribagh, East and West Singhbhum of Jharkhand state. The study area comes under subtropical and sub-humid, with hot wet summer and cool dry winter climate characterized by annual mean temperature of $25.6{ }^{\circ} \mathrm{C}$ and mean summer and mean winter temperature of 29.0 and $21.3{ }^{\circ} \mathrm{C}$, respectively. The monsoon which starts in May and continues up to October is the main source of precipitation. It has an annual average precipitation of $1393 \mathrm{~mm}$. About $82 \%$ of the annual rainfall occurs during the monsoon which lasts roughly from June to September. Sample site of weathered crust are mainly located in three blocks namely Manbazar-I, Manbazar-II and Banduan in southern Purulia district.

\section{Geological settings}

Regionally the area is a part of Chotanagpur Gneissic Complex of Eastern Indian Peninsular Shied, lying to the north of Singhbhum Craton. China clay occurrences of Purulia district are invariably associated with granitic rocks and metasediments of the Chhotanagpur Gneissic Complex of Precambrian age. Dunn and Dey (1942) first described the complex as largely a product of replacement origin. The area is mostly covered by soil and represents undulating topography with moderate to gentle slopes. Purulia has a thick Stratigraphic succession of mostly Archacan granite gneiss (see Table 1) and to a much lesser extent, 
Fig. 1 Location map of the study area and sample sites

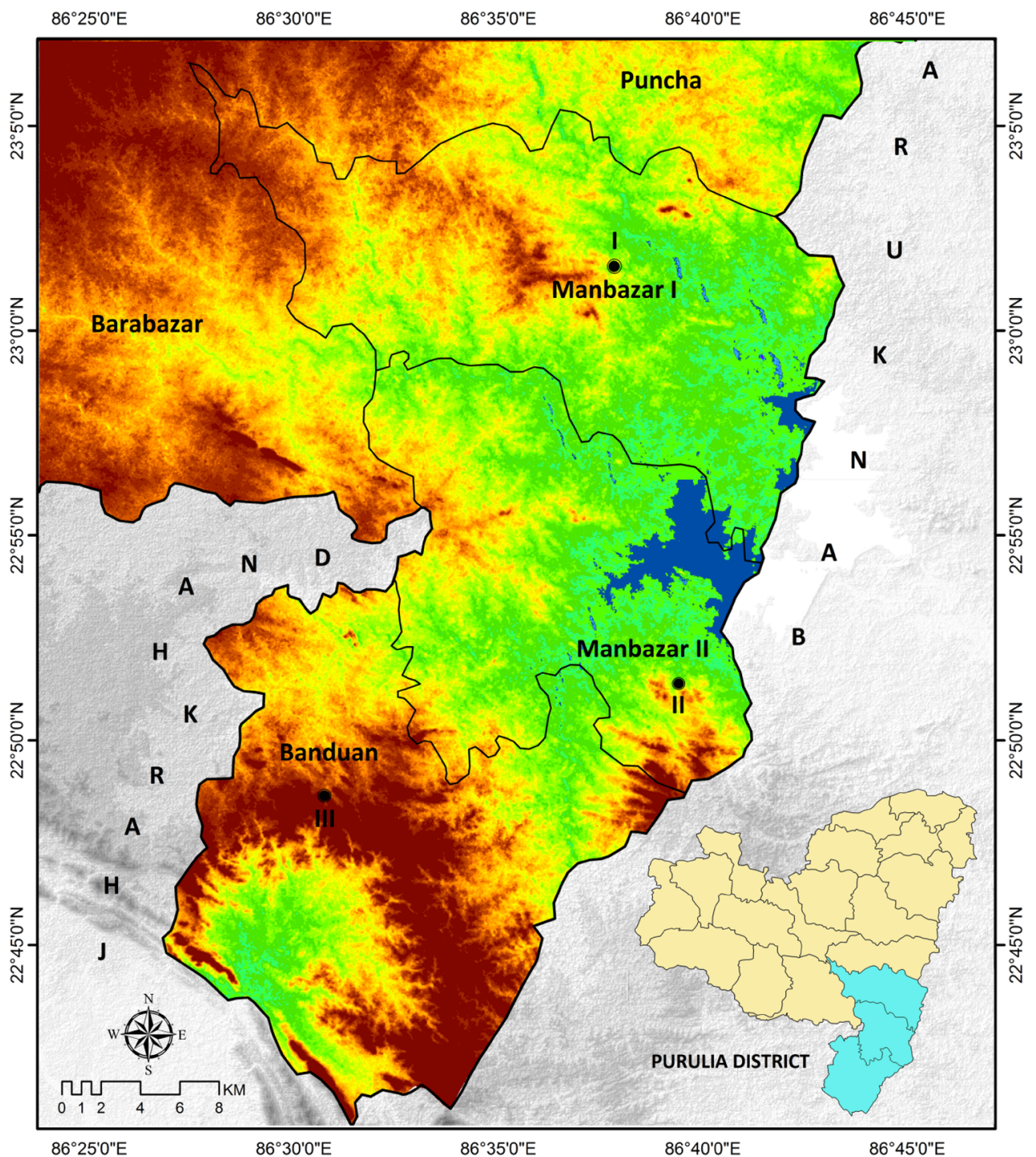

Table 1 Stratigraphic succession in Purulia district

\begin{tabular}{|c|c|c|}
\hline Formation & Age & Lithology \\
\hline Recent alluvium & Recent & Semi consolidated sediments consisting of conglomerates, lateritic and gravel beds \\
\hline Sijua formation & Quaternary & Semi consolidated sediments consisting of gravel bed and conglomerate \\
\hline Gondwana rocks & $\begin{array}{l}\text { Permo } \\
\text { Carboniferous }\end{array}$ & Sandstone shale and coal seams \\
\hline $\begin{array}{l}\text { Quartzite and pegmatite } \\
\text { granite }\end{array}$ & Pre Cambrian & Massive Granites and pegmatite and quartzite veins \\
\hline $\begin{array}{l}\text { Meta volcanics } \\
\text { Metabasic rocks }\end{array}$ & Archacan & $\begin{array}{l}\text { Rock types belong to Chhotanagpur gneissic complex. Granite gneiss with quartz veins and } \\
\text { pegmatite veins }\end{array}$ \\
\hline Phyllite and mica schiest & & Muscovite and biotite schiest, highly foliated \\
\hline
\end{tabular}

Granite gneiss

Calc granulites

Mica schiest

After Dolui et al. (2014); adapted from Geological Survey of India 
Quaternary semi consolidated sediments, Permo Carboniferous sandstone shale, Pre Cambrian massive granites and quartzite and with Recent alluvium sediments deposition. Granite, granite gneiss and phylite \& mica schist are the dominant rocks formed in the southern Purulia district (Fig. 2). Mineralogically these rocks are composed mainly of quartz, feldspar, muscovite, biotite, albite and clay minerals.

\section{Materials and methods}

\section{Field work}

The field survey was based on a detailed observation and description of micro-morphological features and physical nature of the profiles. Some geomorphological and geological techniques were integrated to analyze and understand the weathering processes operating in three sample sites in the study region. Samples from granitic weathering crusts were collected from three sections (14 samples in total) of three different blocks namely, Manbazar-I, Manbazar-II and Banduan situated in the south-eastern part of the Purulia district (Fig. 1). Sampling was restricted mostly within the exposed layers of the respective weathering profile. The samples were collected from different segments of the profiles which are mainly found along the road cuts, natural and other man-made exposures. Samples were collected within the profiles with a particular interval depending upon the lithological and physical characters of the materials and sampling started from the bottom of the profiles.

\section{Weathering profile}

Based on the knowledge obtained from extensive previous works on weathering processes in granitic profiles in several arid to semi arid places in different climatic conditions (Eswaran and Bin 1978a, b; Le Pera et al. 2000; Scarciglia et al. 2005, 2007, 2012; Borrelli et al. 2012, 2014) we selected three representative weathering profiles exposed at surface in southern Purulia district. During the field study sites were carefully observed in order to obtain information about the extension of profile, distribution of materials, geometrical characteristics and some morphological features (color, texture fabric and weathering features) of the different weathered horizons. For the studied weathering profiles, layers are categorized and designated on the basis of visual characteristics fallowing the modified New Zealand Geomechanics Society (NZGS) standards (1988) and also according to the scheme proposed by Gullà and Matano (1997). The NZGS consider four classes-F, SW, MW and HW from the fresh or unweathered parent rock, at the bottom of the profile, to highly weathered saprolite or residual soil, at the top of the profile and Gullà and Matano system classify a weathering crust into four different classes with increasing weathering grade from I to IV (Table 2).

\section{Particle size distribution analysis}

During the alteration of parent rock to soil by intense weathering, the rock forming minerals, which once were bonded with each other, are weathered and altered into distinct particles of different shapes and sizes. The
Fig. 2 Geological formation of the study area. (Source: G.S.I.)

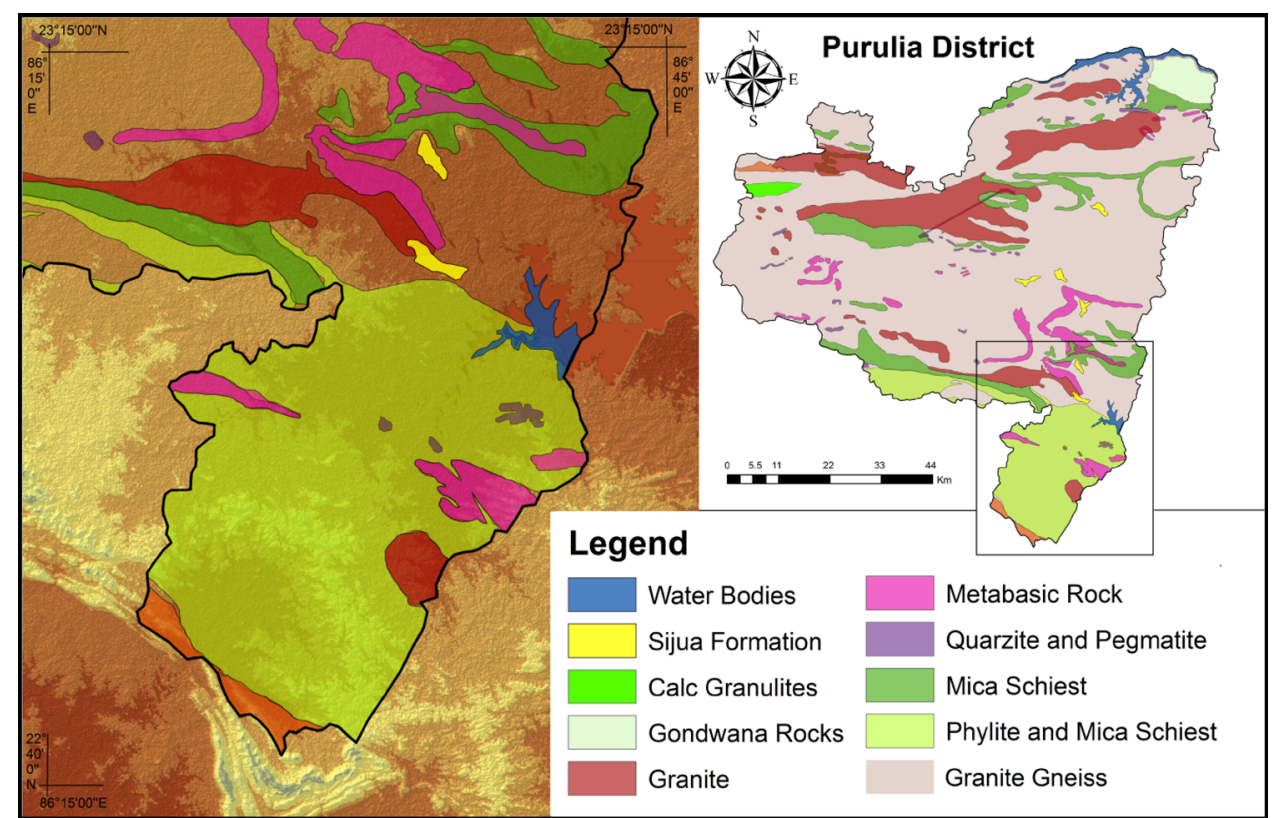


Table 2 Field description of the weathering features according to the weathering classes. (modify after Gullà and Matano 1997; New Zealand Geomechanics Society standards, 1988)

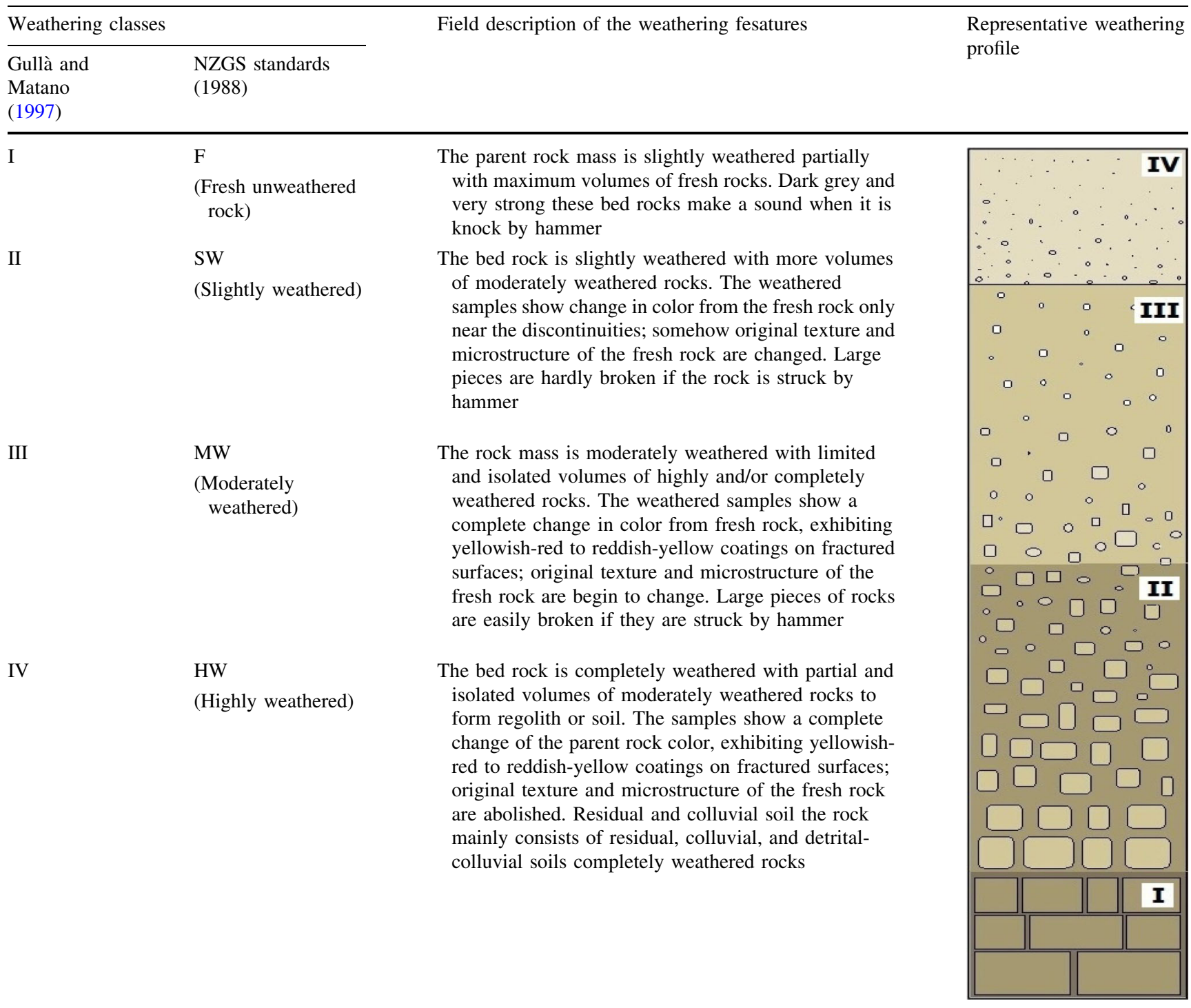

decomposed granite rocks and weathered saprolite or regolith materials generally have very wide range of particle size. Therefore, to understand the particle size distribution throughout the weathered crust, textural analysis of the weathered materials collected across the layers is necessary. Particle size analysis (PSA) is a measurement technique of individual size distribution of particles in soil or weathered rock sample. Soil particles vary largely in size ranging from stones and rocks (more than $0.25 \mathrm{~m}$ in size) down to submicron clays $(<1 \mu \mathrm{m})$. Various systems of size classification are in practice to define random limits and ranges of soil-particle size. In this study, the system of classification used by the US Department of Agriculture
(USDA) has been used to define size classes of the particles.

At first the samples are dried in oven to prepare it for sieve analysis. $100 \mathrm{gm}$ of granitic saprolite and soil materials are taken for sieve analysis. Sieve analysis consists of shaking the samples through a set of sieves (4.75, $3.35,2.0,1.0,0.18$ and $0.09 \mathrm{~mm}$ ) that have progressively smaller openings and weighing of the portion retained. The results of sieve particle size analysis are mainly expressed in terms of the mass of samples that the different sieves retain. Thus, as the percentage of total mass of the sample taken for analysis to find the percentage of samples belonging to the size classes, at first, record the mass of the 
Table 3 Statistical formulae used in the calculation of grain size parameters and suggested descriptive terminology modified after Folk and Ward (1957)

(a) Logarithmic (original) Folk and Ward (1957) graphical measures

\begin{tabular}{|c|c|c|c|c|c|}
\hline \multirow{2}{*}{$\begin{array}{l}\text { Mean } \\
M_{z}=\frac{\emptyset_{16}+\emptyset_{50}+\emptyset_{84}}{3}\end{array}$} & \multicolumn{2}{|c|}{ Standard division } & \multicolumn{2}{|l|}{ Skewness } & Kurtosis \\
\hline & $\sigma_{1}=$ & $\frac{\phi_{95}-\emptyset_{5}}{6.6}$ & $S k_{1}=\frac{\emptyset_{16}+\emptyset_{84}-\emptyset_{50}}{2\left(\emptyset_{84}-\emptyset_{16}\right)}$ & $\frac{-\emptyset_{50}}{\left.-\emptyset_{5}\right)}$ & $K_{G}=\frac{\emptyset_{95}-\emptyset_{5}}{2.44\left(\emptyset_{75}-\emptyset_{25}\right)}$ \\
\hline Sorting $\left(\sigma_{1}\right)$ & & Skewness $\left(S k_{1}\right)$ & & Kurtosis $\left(K_{G}\right)$ & \\
\hline Very well sorted & $<0.35$ & Very fine skewed & ${ }^{+} 0.3$ to ${ }^{+} 1.0$ & Very platykurtic & $<0.67$ \\
\hline Well sorted & $0.35-0.50$ & Fine skewed & ${ }^{+} 0.1$ to ${ }^{+} 0.3$ & Platykurtic & $0.67-0.90$ \\
\hline Moderately well sorted & $0.50-0.70$ & Symmetrical & ${ }^{+} 0.1$ to ${ }^{-} 0.1$ & Mesokurtic & $0.90-1.11$ \\
\hline Moderately sorted & $0.70-1.00$ & Coarse skewed & -0.1 to ${ }^{-} 0.3$ & Leptokurtic & $1.11-1.50$ \\
\hline Poorly sorted & $1.00-2.00$ & Very coarse skewed & ${ }^{-} 0.3$ to ${ }^{-} 1.0$ & Very leptokurtic & $1.50-3.00$ \\
\hline Very poorly sorted & $2.00-4.00$ & & & Extremely leptokurtic & $>3.00$ \\
\hline Extremely poorly sorted & $>4.00$ & & & & \\
\hline
\end{tabular}

(b) Geometric Folk and Ward (1957) graphical measures

\begin{tabular}{|c|c|c|c|c|c|}
\hline \multicolumn{3}{|l|}{ Mean } & & \multicolumn{2}{|l|}{ Standard deviation } \\
\hline \multicolumn{4}{|l|}{$M_{G}=\exp \frac{\operatorname{In} P_{16}+\operatorname{In} P_{50}+\operatorname{In} P_{84}}{3}$} & \multicolumn{2}{|c|}{$\sigma_{G}=\exp \left(\frac{\operatorname{In} P_{15}-\operatorname{In} P_{84}}{4}+\frac{\operatorname{In} P_{5}-\operatorname{In} P_{95}}{6.6}\right)$} \\
\hline \multicolumn{4}{|l|}{ Skewness } & \multicolumn{2}{|c|}{ Kurtosis } \\
\hline \multicolumn{4}{|c|}{$S k_{G}=\frac{\operatorname{In} P_{16}+\operatorname{In} P_{84}-2\left(\operatorname{In} P_{50}\right)}{2\left(\operatorname{In} P_{84}-\operatorname{In} P_{16}\right)}+\frac{\operatorname{In} P_{5}+\operatorname{In} P_{95}-2\left(\operatorname{In} P_{50}\right)}{2\left(\operatorname{In} P_{95}-\operatorname{In} P_{5}\right)}$} & \multicolumn{2}{|c|}{$K_{G}=\frac{\operatorname{In} P_{5}-\operatorname{In} P_{95}}{2.44\left(\operatorname{In} P_{25}-\operatorname{In} P_{75}\right)}$} \\
\hline \multicolumn{2}{|l|}{ Sorting $\left(\sigma_{G}\right)$} & \multicolumn{2}{|l|}{ Skewness $\left(S k_{G}\right)$} & \multicolumn{2}{|l|}{ Kurtosis $\left(K_{G}\right)$} \\
\hline Very well sorted & $<1.27$ & Very fine skewed & ${ }^{+} 0.3$ to ${ }^{+} 1.0$ & Very platykurtic & $<0.67$ \\
\hline Well sorted & $1.27-1.41$ & Fine skewed & ${ }^{+} 0.1$ to ${ }^{+} 0.3$ & Platykurtic & $0.67-0.90$ \\
\hline Moderately well sorted & $1.41-1.62$ & Symmetrical & ${ }^{+} 0.1$ to ${ }^{-} 0.1$ & Mesokurtic & $0.90-1.11$ \\
\hline Moderately sorted & $1.62-2.00$ & Coarse skewed & ${ }^{-} 0.1$ to ${ }^{-} 0.3$ & Leptokurtic & $1.11-1.50$ \\
\hline Poorly sorted & $2.00-4.00$ & Very coarse skewed & ${ }^{-} 0.3$ to ${ }^{-} 1.0$ & Very leptokurtic & $1.50-3.00$ \\
\hline Very poorly sorted & $4.00-16.00$ & & & Extremely leptokurtic & $>3.00$ \\
\hline Extremely poorly sorted & $>16.00$ & & & & \\
\hline
\end{tabular}

portion retained from each sieve and finally in the pan. To do so, the following equation is used

$\mathrm{R} p=\frac{\mathrm{W} s}{\mathrm{~W} t} \times 100 \%$

where, $\mathrm{R} p=$ percentage retained from sieve, $\mathrm{W} s=$ weight of soil sample in the sieve, $\mathrm{W} t=$ total weight of the samples.

The values thus obtained are added cumulatively across the size grades and plotted against size class boundaries to prepare cumulative percentage graphs for each layer of the weathering profiles. However, the particle size distribution curves fails to interpret the nature of size-sorting of the particles across the profiles. Therefore, to interpret properly some statistical measurements are done which quantitatively describe certain feature of the curves.

Particle size distribution analysis is one of the important tools for understanding the erosional and depositional environment. Therefore, particle size analysis makes it easy to understand the sedimentary environments, transport history and nature of depositions (Folk 1954; Folk and Ward 1957; Friedman 1979; Bui et al. 1990). In case of the study area, more than half of the particles are coarser than the median value and rest are finer. Therefore, to understand the distribution pattern of grain size throughout the profiles the GRADISTAT program has been used for measuring the four principal statistics which are (i) the average size or mean, (ii) the sorting pattern around the mean (iii) the preferential spread or symmetry (skewness), and (iv) the degree of concentration of particle (kurtosis) in related to mean (Table 3). GRADISTAT provides rapid calculation of particle size distributional statistics by both moment's methods (Friedman and Johnson 1982) and Folk and Ward (1957) method. 


\section{Mineralogical analysis of samples}

At first, samples were cleaned for geochemical analyses. About 150-200 gm of dried bulk samples was taken for X-ray diffraction (XRD) analysis. To get the powder samples, a small hammer and hand crusher was used to reduce the rock aggregate to smaller particles. X-ray diffraction analysis was performed on the powder samples using X-ray diffractometer PW-17291710 at the department of Chemistry, Indian Institute of Technology, Kharagpur. XRD was done for determining the mineralogical composition of parent rock to weathered rock samples and also determine the nature of geochemical changes throughout the weathering profiles. The step size ${ }^{\circ} 2 \theta\left(0.05^{\circ}\right)$ was taken and the step time was $1 \mathrm{~s}$ with fixed $1 \mathrm{~mm}$ divergence silt in $25^{\circ} \mathrm{C}$ temperature. The scan range was $2^{\circ}-40^{\circ}$ (Dolui et al. 2014). The fractions of powder sample were mounted on a glass slides in order to take a perfect orientation of sample minerals. Quantitative mineralogical analysis of the sample rock was performed measuring random peak areas using $\mathrm{X}$-pert highscore. Geochemical alteration was deduced from the mineralogical composition as observed in the micro-morphological analysis.

Samples of both bedrock and weathered saprolite from three sampled profiles were analysed in thin sections under polarizing optical microscope. Analyses were carried out by Nikon ECLIPSE LV100POL polarizing microscope with fluorescence attachment for episcopic illumination. The digital camera DS-5M and the camera control unit DSL1 are used for micro-morphological photographs.

Fig. 3 Typical granitic weathering profile for regolith or soil development in the study area

\section{Geochemical reaction modelling}

Under dissolved condition some minerals undergo hydrolysis to release a different mineral into solution with the probable formation of one or additional solid products. According to Steinmann et al. (1994), "the successive changes in the composition of the solution with continued reaction are referred to as a reaction path". Reaction path modelling of weathering reactions of different minerals was introduced by Helgeson (1968). So, mineralogical alterations of different parent rocks during intense weathering are to be understood by the geochemical reaction pathways of different minerals. Whereas, the primary minerals of parent rock in any weathering profile are gradually altered to secondary minerals to formed soil or regolith.

During intense weathering of granitic rocks, rockforming primary minerals are considerably changed to secondary clay minerals by different chemical weathering processes such as hydrolysis, hydration etc. (Fig. 3). Where, some new secondary minerals such as illite, gibbsite, smectite etc. are the most primitive to be produced followed by montmorillonite, kaolinite and halloysite (Islam et al. 2002). Banfield and Eggleton (1988) reported by TEM study in New South Wales, Australia that vermiculite, kaolinite and goethite are initially formed by the weathering of biotite. In the advanced stage of weathering, Islam et al. (2002) also reported that, K-feldspar also turn into secondary clay minerals such as illite and kaolinite which is also supported by Ehlmann (1968). Formation of kaolinite from biotite is very common under an extreme
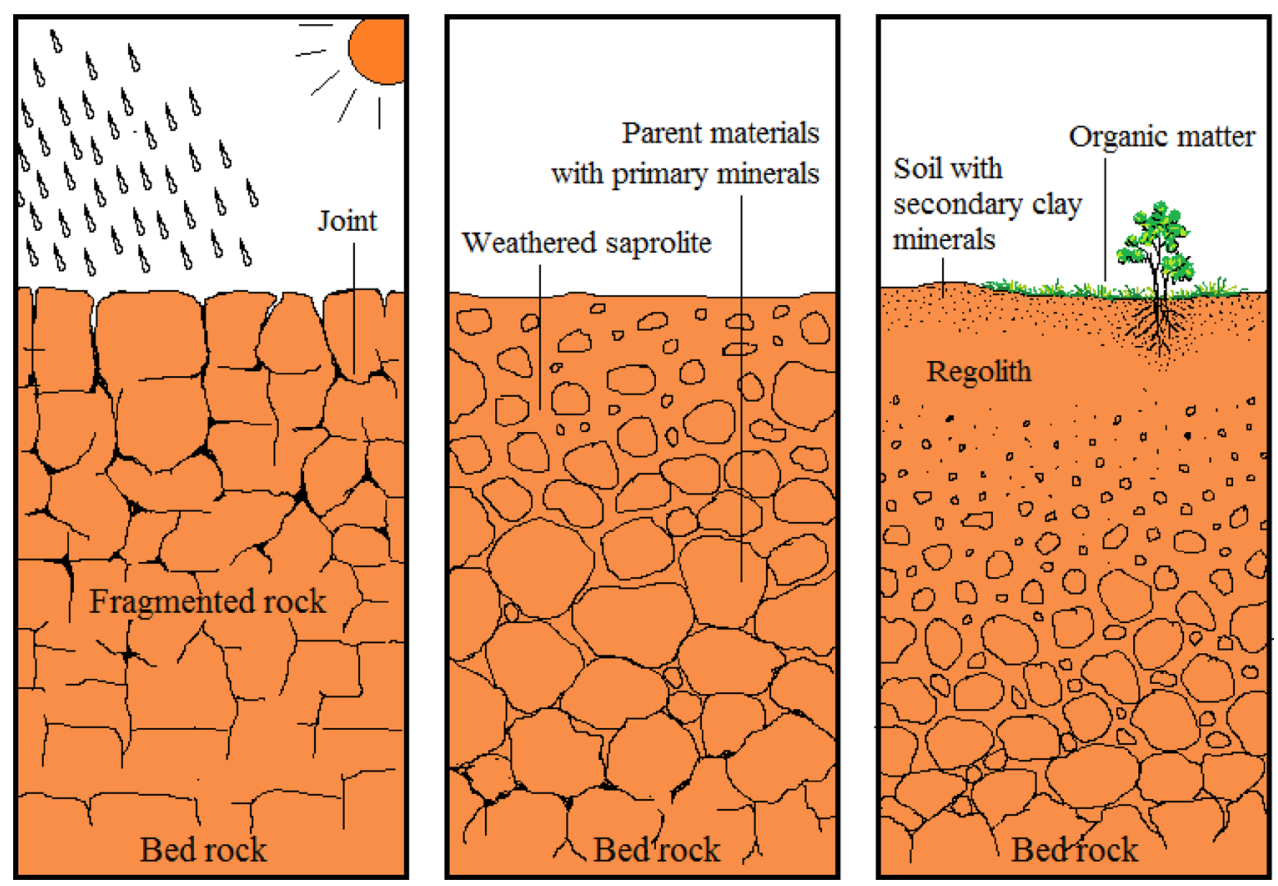


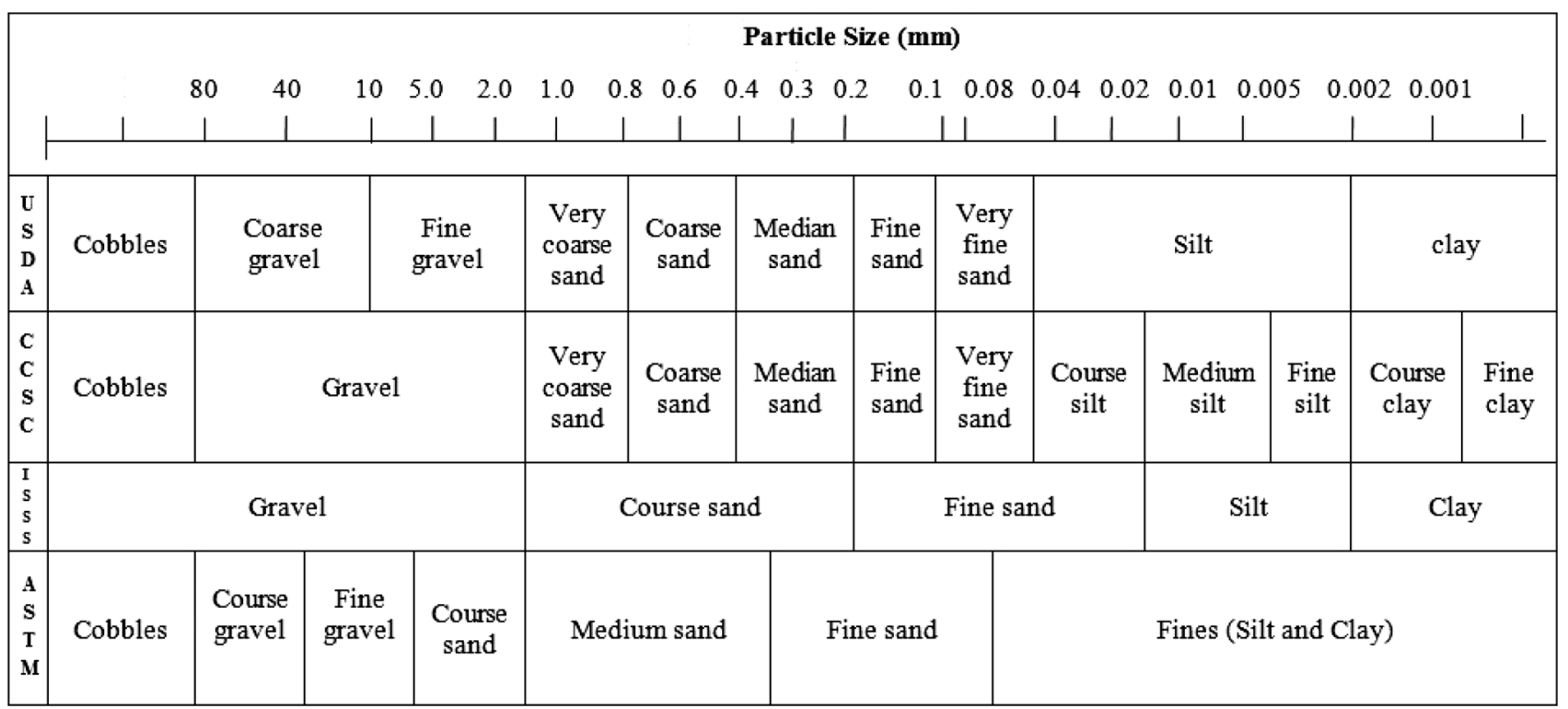

Fig. 4 Particle size limits according to several current classification schemes. USDA, U.S. Department of Agriculture (Soil Survey Staff 1975); ISSS, International Soil Sci. Soc., (Yong and Warkentin 1966);

weathering condition (Wilson 1975) predominantly in tropical to subtropical hot humid climates (Novikoff et al. 1972; Eswaran and Heng 1976; Eswaran and Bin 1978a, b; Paven et al. 1981). According to Helgeson (1968) in an aqueous solution initially K-feldspar dissolves while gibbsite precipitates according to the reaction:

$\mathrm{KAlSi}_{3} \mathrm{O}_{8}+\mathrm{H}^{+}+7 \mathrm{H}_{2} \mathrm{O}=\mathrm{Al}(\mathrm{OH})_{3}+\mathrm{K}^{+}+3 \mathrm{H}_{4} \mathrm{SiO}_{4}$ Microcline

$$
\text { gibbsite }
$$

The reaction continues to achieve a state of equilibrium condition by formation of kaolinite.

$$
\begin{aligned}
& \mathrm{KAlSi}_{3} \mathrm{O}_{8}+2 \mathrm{Al}(\mathrm{OH})_{3}+\mathrm{H}^{+}=1.5 \mathrm{Al}_{2} \mathrm{Si}_{2} \mathrm{O}_{5}(\mathrm{OH})_{4}+\mathrm{K}^{+} \\
& \text {Microcline gibbsite } \\
& +0.5 \mathrm{H}_{2} \mathrm{O}
\end{aligned}
$$

Jiménez-Millán et al. (2007) stated that, by the solutionprecipitation process the feldspar alters into secondary clay minerals where as biotite is gradually replaced by kaolinite. During intense chemical weathering of granitic rock feldspar is found to alter into illite and gradually illite into kaolinite because according to Harris and Adams (1966) at the extreme stage of weathering silicate clay minerals are altered to secondary clay minerals. In the tropical to subtropical environment Wilson (2004) found that secondary clay minerals are generally formed from biotite. As feldspar and biotite of granite rock are affected at the early stage of weathering, there is a possible way that kaolinite is formed from biotite via vermiculite (Fig. 4). Quartz is
ASTM (Unified), American Society for Testing and Materials (ASTM, D-2487, 2000)

stable with its dissolve condition for its less susceptibility to weathering.

$$
\begin{aligned}
& 2 \mathrm{~K} \mathrm{Al} \mathrm{Si}{ }_{3} \mathrm{O}_{8}+2 \mathrm{H}_{2} \mathrm{O}+\mathrm{CO}_{2} \rightarrow \mathrm{Al}_{2} \mathrm{Si}_{2} \mathrm{O}_{5}(\mathrm{OH})_{4}+\mathrm{K}_{2} \mathrm{CO}_{3} \\
& \text { Feldspar } \\
& +4 \mathrm{SiO}_{2}
\end{aligned}
$$

$$
\begin{aligned}
& \mathrm{K} \mathrm{Al} \mathrm{Si}{ }_{3} \mathrm{O}_{8}+\mathrm{CO}_{2}+3 \mathrm{H}_{2} \mathrm{O} \rightarrow \mathrm{Al}_{2} \mathrm{Si}_{2} \mathrm{O}_{5}(\mathrm{OH})_{4}+\mathrm{Na}^{+} \\
& \text {Kaolinite } \\
& +2 \mathrm{SiO}_{2}+\mathrm{HCO}_{3}^{-}
\end{aligned}
$$

$\mathrm{K} \mathrm{Al} \mathrm{Si}_{3} \mathrm{O}_{8}+\mathrm{CO}_{2}+2 \mathrm{H}_{2} \mathrm{O} \rightarrow \underset{\text { Gibbsite }}{\mathrm{Al}(\mathrm{OH})_{3}}+\mathrm{K}++3 \mathrm{SiO}_{2}$ $+\mathrm{HCO}_{3}-$

$6 \mathrm{~K}\left(\mathrm{Al} \mathrm{Si} \mathrm{O}_{8}\right)+4 \mathrm{H}_{2} \mathrm{O}+4 \mathrm{CO}_{3}$ Orthoclase

$\rightarrow \underset{\text { Illite }}{\mathrm{K}_{2} \mathrm{Al}_{4}}\left(\mathrm{Si}_{6} \mathrm{Al}_{2} \mathrm{O}_{20}\right)(\mathrm{OH})_{4}+12 \mathrm{SiO}_{2}+\underset{\text { solution }}{4 \mathrm{~K}^{+}}+4 \mathrm{HCO}_{3}$

$$
\begin{gathered}
2 \mathrm{~K} \mathrm{Al}_{5} \mathrm{Si}_{7} \mathrm{O}_{20}(\mathrm{OH})_{4}+2 \mathrm{H}_{2} \mathrm{O}+2 \mathrm{CO}_{3}+13 \mathrm{H}_{2} \mathrm{O} \\
\text { Illite } \\
\rightarrow \underset{\text { Kaolinite }}{5 \mathrm{Al}_{2} \mathrm{Si}_{2} \mathrm{O}_{5}(\mathrm{OH})_{4}}+4 \mathrm{H}_{4} \mathrm{SiO}_{4}+2 \mathrm{~K}^{+} 2 \mathrm{HCO}_{3}^{-}
\end{gathered}
$$
$\underset{\text { Albite }}{\mathrm{Na} \mathrm{Si}} \mathrm{O}_{8}+\mathrm{CO}_{2}+2 \mathrm{H}_{2} \mathrm{O} \rightarrow \underset{\text { Gibbsite }}{\mathrm{Al}(\mathrm{OH})_{3}}+\mathrm{Na}^{+}+3 \mathrm{SiO}_{2}$ $+\mathrm{HCO}_{3}^{-}$

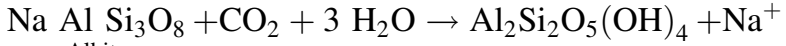 Albite $+2 \mathrm{SiO}_{2}+\mathrm{HCO}_{3}^{-}$




\section{REACTIONS IN CHEMICAL WEATHERING OF GRANITIC ROCK}

GOLDICH'S

WEATHERING SERIES

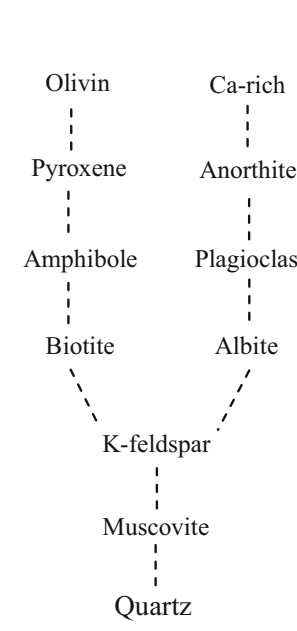

\section{Hydrolysis reactions}

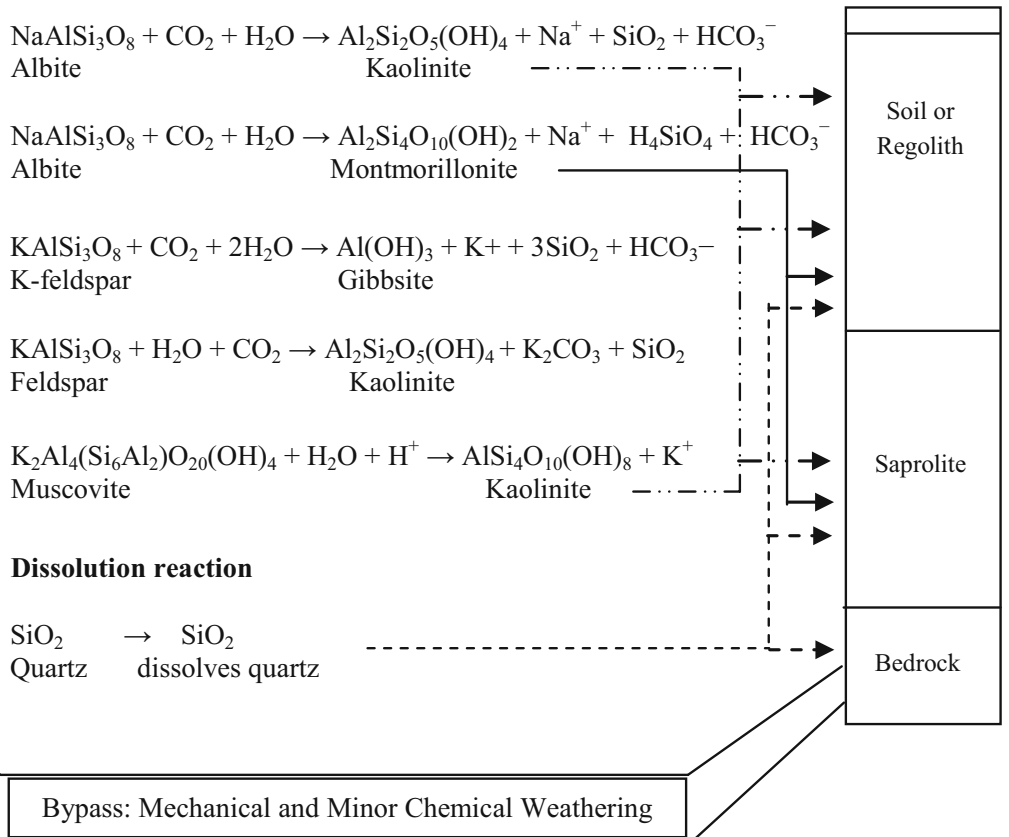

Fig. 5 Geochemical reaction modelling in chemical weathering throughout the weathering profile of granitic rocks

Fig. 6 Pathways of formation of secondary minerals in weathering profiles. (modified from Anand and Paine 2002; and compiled from Gilkes et al. 1973; Anand and Gilkes 1984a, b; Singh and Gilkes 1991)

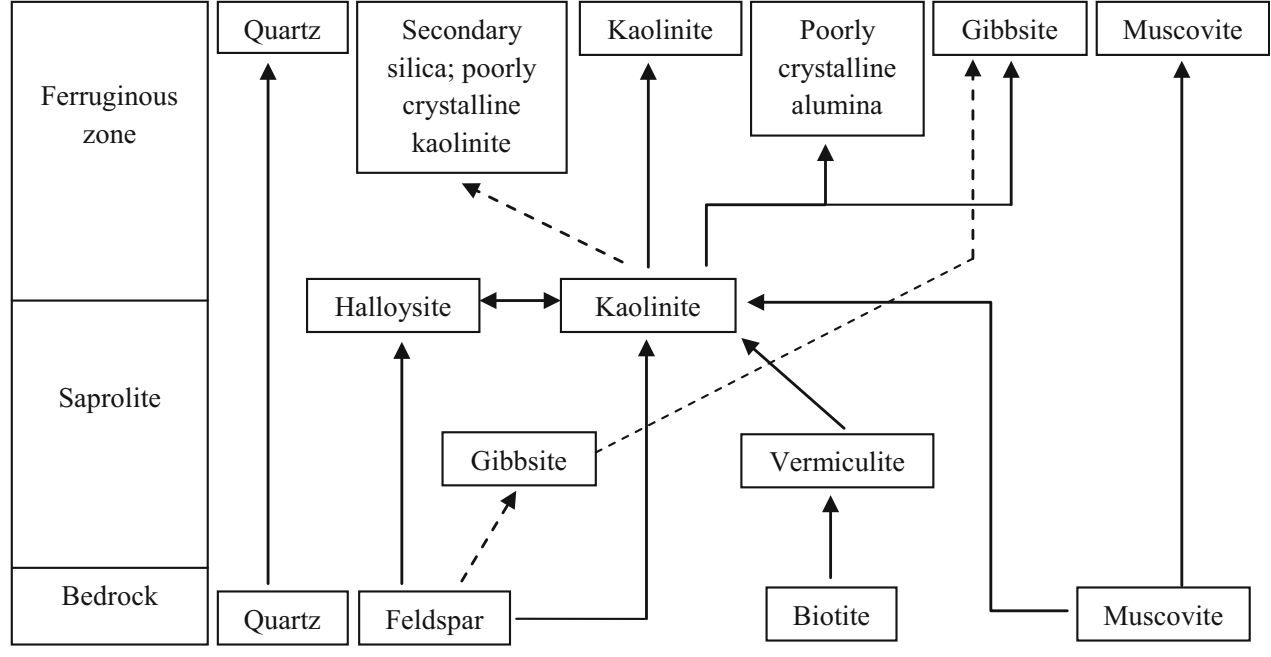

$2 \mathrm{Na} \mathrm{Al} \mathrm{Si}{ }_{3} \mathrm{O}_{8}+2 \mathrm{CO}_{2}+6 \mathrm{H}_{2} \mathrm{O}$

Albite

$\rightarrow \mathrm{Al}_{2} \mathrm{Si}_{4} \mathrm{O}_{10}(\mathrm{OH})_{2}+2 \mathrm{Na}^{+}+2 \mathrm{H}_{4} \mathrm{SiO}_{4}+2 \mathrm{HCO}_{3}^{-}$ Montmorillonite

$2 \mathrm{~K}_{2} \mathrm{Al}_{4}\left(\mathrm{Si}_{6} \mathrm{Al}_{2}\right) \mathrm{O}_{20}(\mathrm{OH})_{4}+6 \mathrm{H}_{2} \mathrm{O}+4 \mathrm{H}^{+}$

Muscovite

$\rightarrow \underset{\text { Kaolinite }}{3 \mathrm{Al} \mathrm{Si} \mathrm{O}_{40} \mathrm{O}_{10}(\mathrm{OH})_{8}}+4 \mathrm{~K}^{+}$

$\mathrm{SiO}_{2} \rightarrow \quad \mathrm{SiO}_{2}$

Quartz dissolvequartz

\section{Results and discussion}

\section{Results}

Field observations

The selected three weathering profile of Manbazar-I, Manbazar-II and Banduan are characterized by four categories of weathering class (Table 2), ranging from 
Fig. 7 Changing distributional pattern of different particle size throughout the different weathering class in 3 sample profile
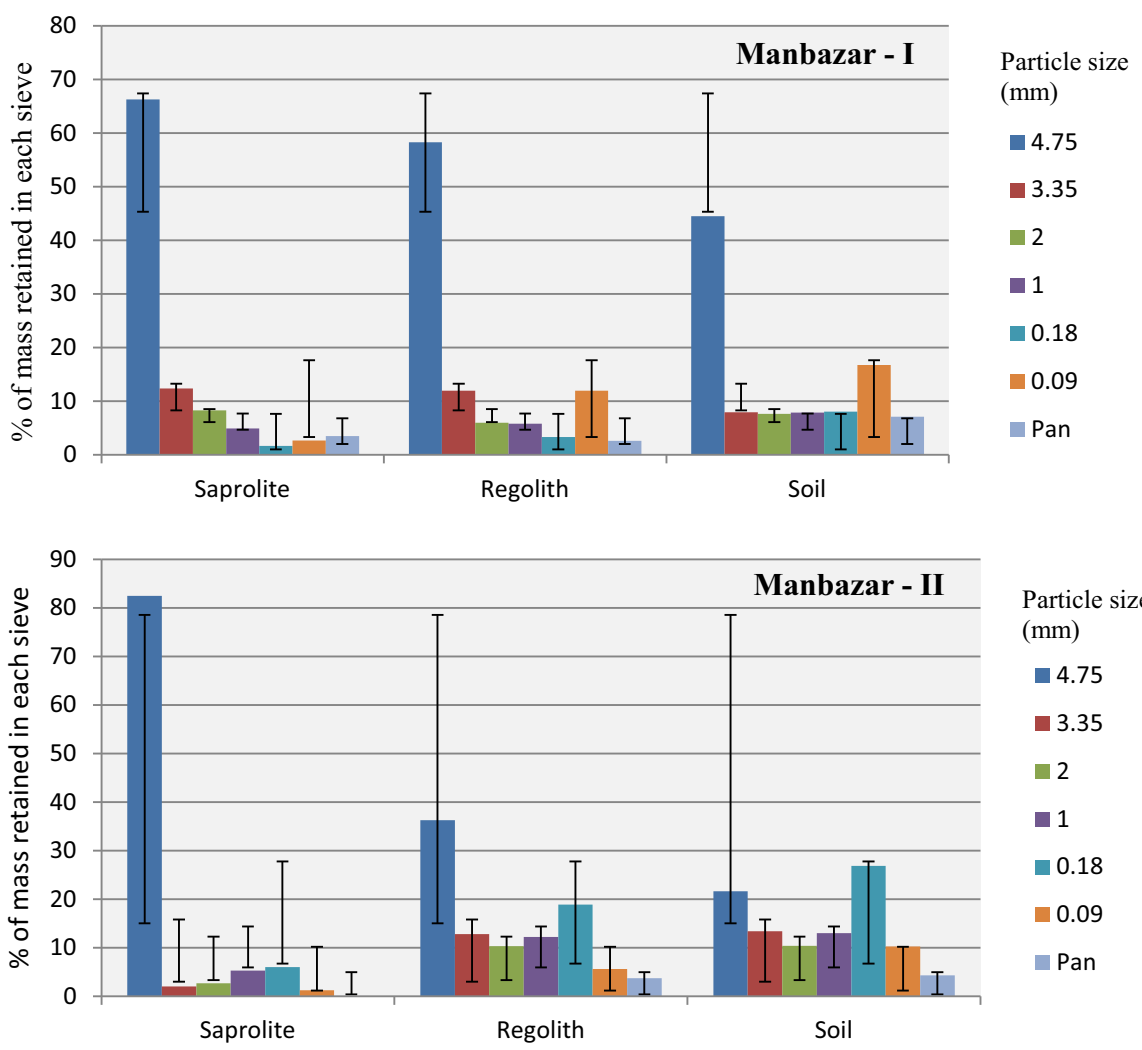

Particle size (mm)

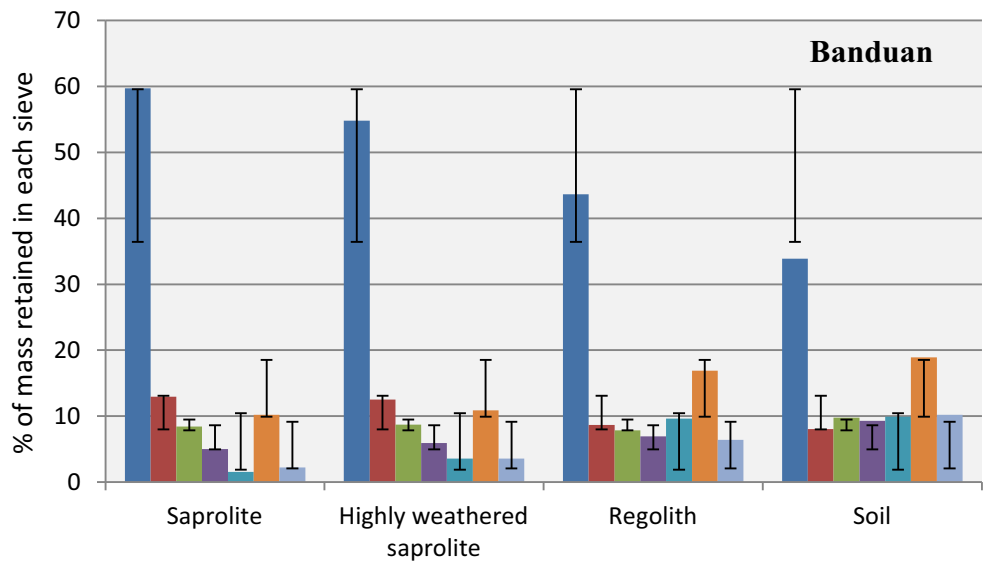

Particle size (mm)

4.75

- 3.35

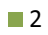

$\square 1$

0.18

0.09

Pan the class IV (highly weathered rock) to the class I (fresh bed rock). Those profiles can be denoted as simple-type weathering profile because those profiles are characterized by gradual changes of parent rocks throughout the profile from hard to slightly weathered rocks (along the base of the profile) to totally weathered rocks with soil formation (on the top of the profile) (Fig. 5). However, between the different weathering classes mainly in lower portion of the profiles, some clear contacts are found where fractured zones are present (Fig. 6). Generally, development of residual soil and regolith (class IV) is limitedly (1-2 $\mathrm{m}$ in thickness) found to occur on top of the weathering crust, although, soil coverage are widely exposed at the surface and is often affected by different erosion processes (Le Pera et al. 2000; Scarciglia et al. 2007). The intensity of alteration processes by physically and chemically shows a more complex pattern of spatial distribution of weathering class which varies profile to profile due to the structural and compositional differentiation of bedrocks. Therefore, the thickness and textural compositions of soil layer are varies between the profiles. There is a clear indication of progressive change in color form un-weathered granitic parent rock to the overlying soil relation to the increasing trend of weathering class. The different classes from I to IV (Table 2) show dark grey (presence of biotite) and yellowish 
Fig. 8 Cumulative distribution of soil particle size in different weathered layer (Manbazar-I, Manbazar-II and Banduan profile)

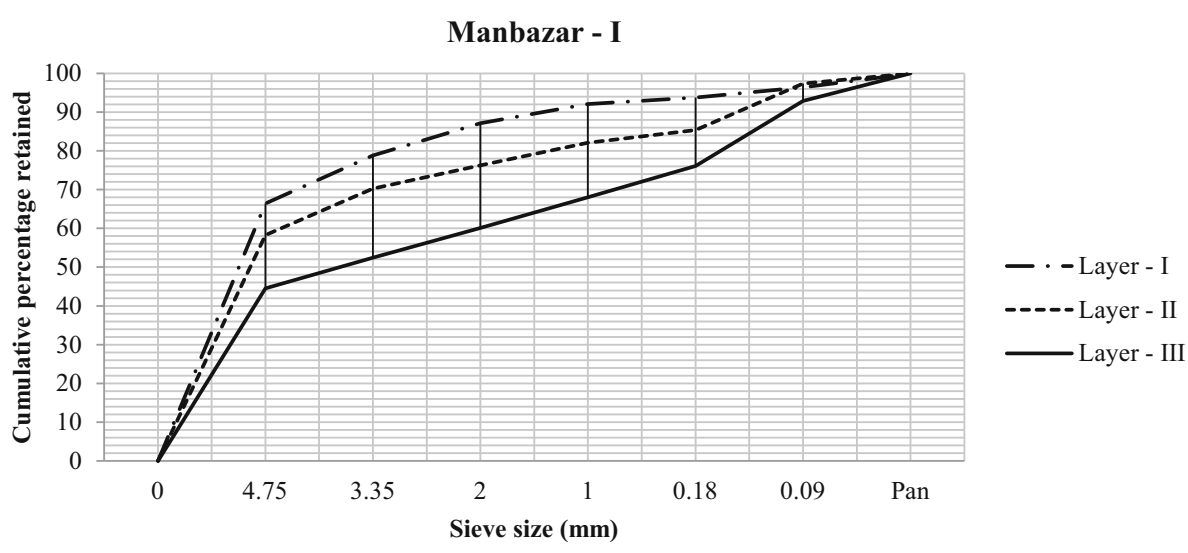

Manbazar - II

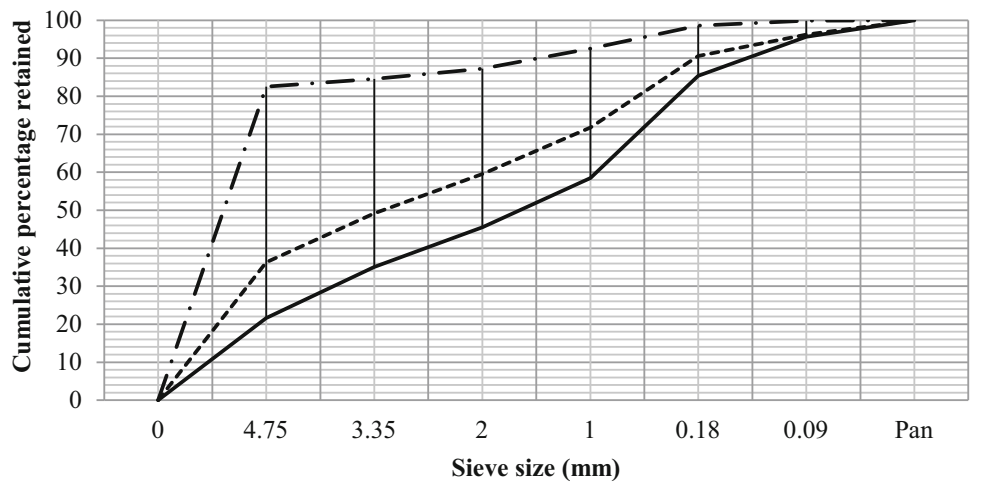

- - - Layer - I
---- Layer - II
- Layer - III

Banduan

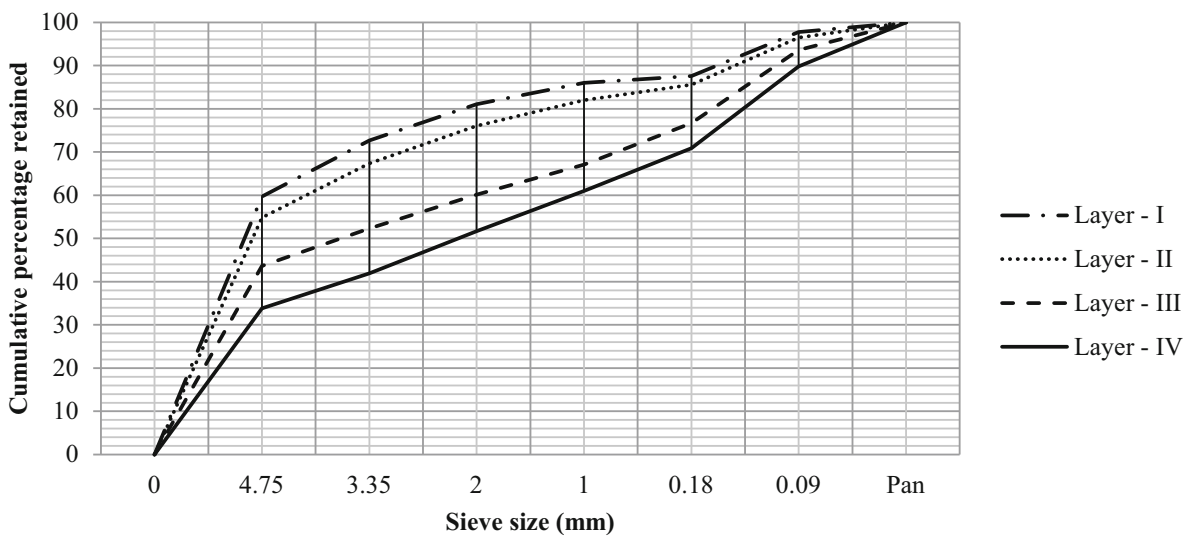

brown (to black) in bedrocks to yellowish-red or reddishyellow and light grey (clay-rich pedogenic matrix) in the soil overlying in the profile. These features reveal that a progressive transformation of primary minerals (by hydrolysis of feldspar, exfoliation of biotite and oxidation) of parent rock mass to formed a pedogenic substances of clay-rich soil and/or quartz-rich sandy soil with course texture at the top of weathering crust (Fig. 7).

\section{Particle size distribution analysis}

Particle size analysis using sieve sets provides particle size distribution pattern for the weathering profiles of three selected sites. Cumulative percentage retained in each sieve and percent finer are evaluate to understand the nature of grain size distribution in relation to physical disintegration. The results of the sieve particle size analysis reveal that for more than $81 \%$ of the samples of the 

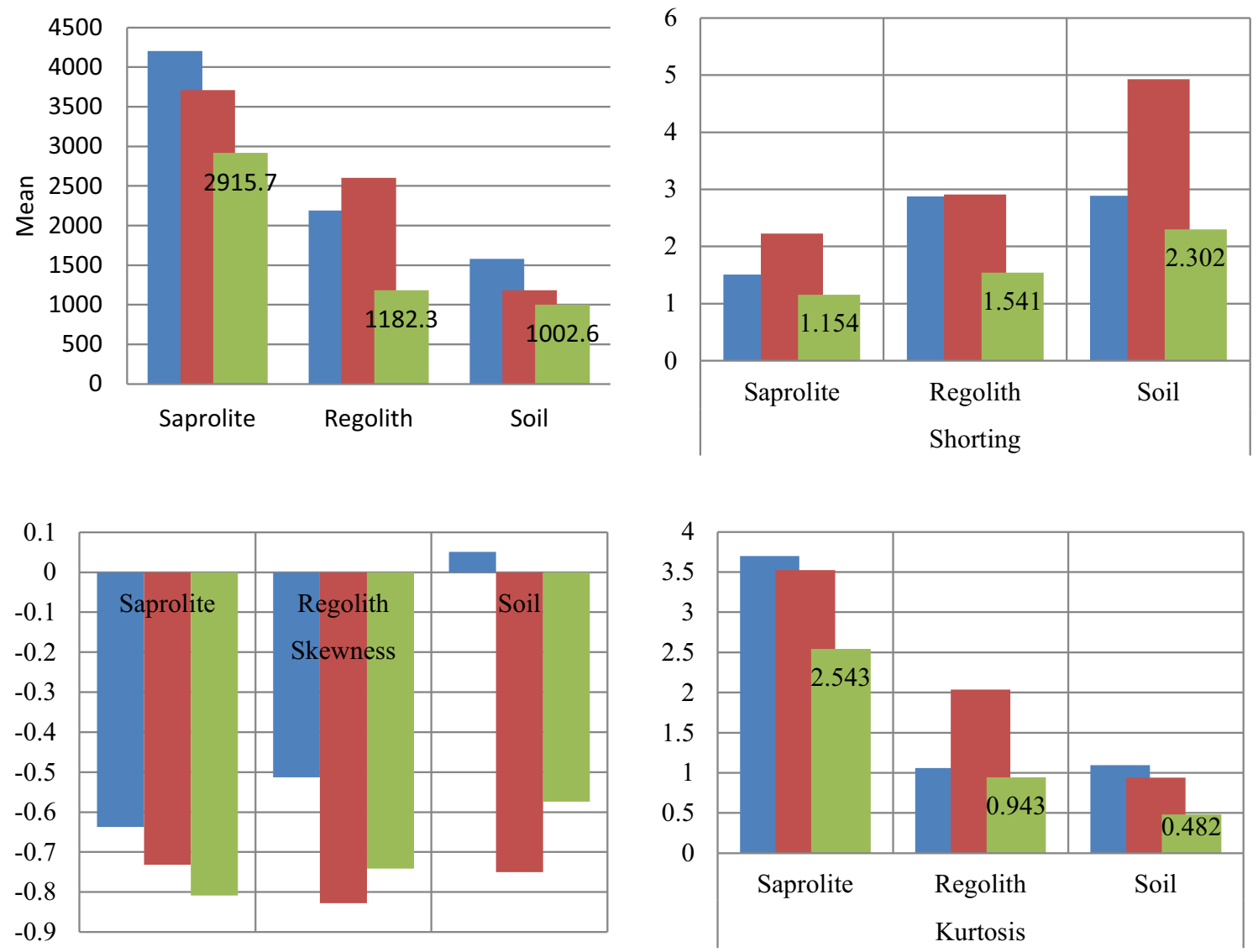

\section{Manbazar - I Manbazar - II Banduan}

Fig. 9 Distribution of the mean, sorting, skewness and kurtosis (in mm unit) after Folk and Ward method of soil samples collected from the study profiles

saprolite come under $2.0 \mathrm{~mm}$ sieve size and under coarse to fine gravels materials according to USDA classification, 1975 (Fig. 8). More than $52 \%$ of the samples of soil overlaying in all profiles comes under $2.0 \mathrm{~mm}$ in size indicates coarse to fine gravels materials. Very poor amount of silt or fine materials (less than $15 \%$ ) are find to occur in the overlaying layer throughout the all profiles. Figure 9 shows that the particle size distributional pattern in different stage of weathering throughout all profiles, where coarse gravel materials $(4.75 \mathrm{~mm})$ are predominantly observed in the saprolite of all profiles. The large size materials are gradually decreased towards the regolith and soil and simultaneously increase the finer materials in upper crust of the profiles. Table 4 also shows that percentage of gravel retained from sieve is gradually decrease in saprolite to soil such as in Manbazar-I profiles 45.38-23.65\%, in Manbazar-II profiles 38.97-26.89\%, and in Banduan profiles 42.03-26.80\%. On the hand, percentage of sand and finer materials (silt and clay) is gradually increased throughout the profiles. In the
Manbazar-I, Manbazar-II and Banduan profile changing percentage of sand in saprolite to soil are 13.75-48.45, 20.80-50.46, and $15.39-45.44 \%$ respectively and the percentage of finer materials are 5.53-57.52, 13.92-53.42, and $19.21-44.86 \%$ respectively.

\section{Mineralogical analysis}

Geologically the study area is covered mainly by granite, granite gneiss and fairly phyllite and mica-schist types of rocks. Therefore, quartz, feldspar (both microcline and albite), biotite and muscovite are identified as primary minerals by X-ray diffraction analysis. The most important secondary clay minerals are montmorillonite, kaolinite and illite including some opaque minerals such as saponite and alumina in the soil, found to occur at the top of the weathered crust. Table 5 shows the nature abundance of minerals determined by XRD in different layer of the profiles. Where, quartz is identified by its typical 3.34 and $4.27 \AA$ peaks. K-feldspar and plagioclase feldspar are 
Table 4 Measurement of sorting, skewness and kurtosis of particle size distribution data by GRADISTAT programme after Folk and Ward method

\begin{tabular}{|c|c|c|c|c|}
\hline & & Saprolite & Regolith & Soil \\
\hline \multicolumn{5}{|l|}{ MANBAZAR-I } \\
\hline & Mean & 4203.0 & 2191.7 & 1578.3 \\
\hline & Sorting & 1.507 & 2.878 & 2.887 \\
\hline & Skewness & -0.637 & -0.513 & 0.051 \\
\hline & Kurtosis & 3.699 & 1.060 & 1.096 \\
\hline \multirow[t]{4}{*}{ Folk and ward method (f) } & Mean & -2.071 & -1.132 & -0.658 \\
\hline & Sorting & 0.592 & 1.525 & 1.530 \\
\hline & Skewness & 0.637 & 0.513 & -0.051 \\
\hline & Kurtosis & 3.699 & 1.060 & 1.096 \\
\hline \multirow[t]{4}{*}{ Folk and ward method (description) } & Mean & Fine gravel & Very fine gravel & Very coarse sand \\
\hline & Sorting & Moderately well sorted & Poorly sorted & Poorly sorted \\
\hline & Skewness & Very fine skewed & Very fine skewed & Symmetrical \\
\hline & Kurtosis & Extremely leptokurtic & Mesokurtic & Mesokurtic \\
\hline \multicolumn{5}{|l|}{ MANBAZAR-II } \\
\hline \multirow[t]{4}{*}{ Folk and ward method $(\mathrm{mm})$} & Mean & 3708.8 & 2600.9 & 1184.0 \\
\hline & Sorting & 2.226 & 2.911 & 4.930 \\
\hline & Skewness & -0.732 & -0.828 & -0.750 \\
\hline & Kurtosis & 3.524 & 2.035 & 0.940 \\
\hline \multirow[t]{4}{*}{ Folk and ward method (f) } & Mean & -1.891 & -1.379 & -0.244 \\
\hline & Sorting & 1.154 & 1.541 & 2.302 \\
\hline & Skewness & 0.732 & 0.828 & 0.750 \\
\hline & Kurtosis & 3.524 & 2.035 & 0.940 \\
\hline \multirow[t]{4}{*}{ Folk and ward method (description) } & Mean & Very fine gravel & Very fine gravel & Very coarse sand \\
\hline & Sorting & Poorly sorted & Poorly sorted & Very poorly sorted \\
\hline & Skewness & Very fine skewed & Very fine skewed & Very fine skewed \\
\hline & Kurtosis & Extremely leptokurtic & Very leptokurtic & Mesokurtic \\
\hline \multicolumn{5}{|l|}{ BANDUAN } \\
\hline \multirow[t]{4}{*}{ Folk and ward method $(\mathrm{mm})$} & Mean & 2915.7 & 1182.3 & 1002.6 \\
\hline & Sorting & 2.670 & 4.890 & 5.021 \\
\hline & Skewness & -0.809 & -0.741 & -0.574 \\
\hline & Kurtosis & 2.543 & 0.943 & 0.482 \\
\hline \multirow[t]{4}{*}{ Folk and ward method (f) } & Mean & -1.544 & -0.242 & -0.004 \\
\hline & Sorting & 1.417 & 2.290 & 2.328 \\
\hline & Skewness & 0.809 & 0.741 & 0.574 \\
\hline & Kurtosis & 2.543 & 0.943 & 0.482 \\
\hline \multirow[t]{4}{*}{ Folk and ward method (description) } & Mean & Very fine gravel & Very coarse sand & Very coarse sand \\
\hline & Sorting & Poorly sorted & Very poorly sorted & Very poorly sorted \\
\hline & Skewness & Very fine skewed & Very fine skewed & Very fine skewed \\
\hline & Kurtosis & Very leptokurtic & Mesokurtic & Very platykurtic \\
\hline
\end{tabular}

identified by its 3.25 and $3.20 \AA$ peak respectively.

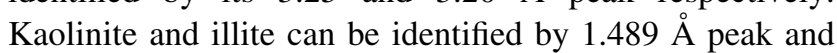
10 and $13.7 \AA$ A peaks (Dolui et al. 2014). Another important clay mineral montmorillonite is also determined by its 5.14 $8.949 .95 \AA$ peaks.

Some unaltered primary minerals are observed in some partly weathered rocks between II and III weathering grades in all the three profiles. Soils developed at the profiles include fragmented rocks particles and quartz (as smaller grains) along with the primary minerals such as muscovite, biotite, and feldspar occurring as primarily altered minerals. Montmorillonite clay mineral is the most abundant secondary minerals found to occur mainly in Manbazar-I and Manbazar-II profiles 
Table 5 Semi-quantitative abundance of minerals throughout the weathering profile from the study area indicated by XRD analysis

\begin{tabular}{|c|c|c|c|c|c|c|c|c|c|}
\hline \multirow[t]{2}{*}{ Profile } & \multirow[t]{2}{*}{ Rock type } & \multirow{2}{*}{$\begin{array}{l}\text { Weathering } \\
\text { grade }\end{array}$} & \multicolumn{4}{|c|}{ Original minerals } & \multicolumn{3}{|l|}{ Derived minerals } \\
\hline & & & Quartz & Feldspar & Biotite & Muscovite & Montmorillonite & Kaolinite & Illite \\
\hline \multirow{5}{*}{$\begin{array}{l}\text { MANBAZAR- } \\
\text { I }\end{array}$} & Granite gneiss & Parent rock & $* * * * * *$ & $* * * *$ & $* * * *$ & $* *$ & & & \\
\hline & Granite gneiss & Saprolite & $* * * * * *$ & $* * * *$ & $*$ & $* * *$ & $* * *$ & & \\
\hline & & & & $\begin{array}{l}\text { (Microcline) } \\
* * * \\
\text { (Albite) }\end{array}$ & & & & & \\
\hline & Granite gneiss & Regolith & $* * * * * *$ & $* * *$ & & & $* *$ & $* * *$ & \\
\hline & & & (SG) & (Alt) & & & & & \\
\hline \multirow{3}{*}{$\begin{array}{l}\text { MANBAZAR- } \\
\text { II }\end{array}$} & Granite & Parent rock & $* * * * * * *$ & $* *$ & & $* * * * *$ & & & \\
\hline & Granite & Weathered rock & $* * * * *$ & $*$ & & $* * * * *$ & $* * *$ & & \\
\hline & & & (SG) & & & (Alt) & & & \\
\hline \multirow[t]{3}{*}{ BANDUAN } & $\begin{array}{l}\text { Granite and } \\
\text { Phyllite }\end{array}$ & Parent rock & $* * * *$ & & $* *$ & $* * * *$ & $* *$ & & \\
\hline & $\begin{array}{l}\text { Granite and } \\
\text { Phyllite }\end{array}$ & Saprolite & $* * * * * *$ & & $* * *$ & & $* * * * * * * * *$ & & $* * * *$ \\
\hline & $\begin{array}{l}\text { Granite and } \\
\text { Phyllite }\end{array}$ & Regolith & $\begin{array}{l}* * * * \\
(\mathrm{SG})\end{array}$ & & $* *$ & $\begin{array}{l}* * * * * \\
\text { (Alt) }\end{array}$ & $* * * * *$ & $* *$ & \\
\hline
\end{tabular}

$(A l t)$ altered, $(S G)$ smaller grain, $(*)$ increasing intensity

where, kaolinite and illite are the important clay minerals in case of Banduan profile. The transition zone between saprolite and regolith of the Manbazar-I weathering crust shows that feldspar (both microcline and albite) is mostly present as primarily altered mineral, while biotite and muscovite are completely altered into clay minerals. But in Manbazar-II and Banduan profiles primarily altered muscovite is present across saprolite and overlying soil layer. Quartz is thus only mineral present throughout all the profiles as small grains or in dissolves condition due to its heights resistance to weathering. The phyllosilicates clay minerals are mostly occur in highly to completely weathered rock/residual soil (class III-IV) than the unweathered bedrock (class I), whereas both plagioclase and K-feldspar, muscovite and biotite are observed decreasing in amount from unweathered fresh bedrock to overlaying residual soil sample (Fig. 10).

From thin sections of weathered rocks under fluorescence optical microscope quartz, feldspar, muscovite and biotite were identified as primary minerals (Fig. 11). In Manbazar-I profile, quartz is the dominant primary minerals (Fig. 11a, b) rather than feldspar (both microcline and albite). From the thin section of Manbazar-II association of quartz and muscovite are dominant than feldspar (Figs. 11c, 13e). The secondary minerals present in weathered saprolite in all of these weathering profiles were very difficult to identify under optical microscope. From the Fig. 11d, f the physical fractures and etchings along the cleavage and fracture planes of the primary minerals are seen clearly.

\section{Discussion}

In tropical to subtropical region geochemical weathering is an important mechanism for modification and alteration of physical, chemical and mechanical properties of granitic rocks (Chiu and Ng 2014). The present study has been carried out in a subtropical humid region where country rocks undergo important chemical alterations in addition to physical disintegration. The results of sieve particle size analysis shows that the coarse to fine gravel materials are the mostly abundant in the saprolite and the layer adjoining to the bedrocks in all profiles. These gravel materials are gradually reduced in size and alter to finer materials such as fine sand, silt and clay through physical and chemical processes (Fig. 9). These changes are noticeable in all the weathering profiles but more conspicuous in Manbazar-II profile. The cumulative percentage distribution of particle size (Fig. 12) reveals that the coarser materials (more than $2.0 \mathrm{~mm}$ ) in primary stage of weathering (saprolite) occupy more than $70 \%$ by weight which explains sudden rise in cumulative curve but the finer materials (less than $1.0 \mathrm{~mm}$ ) in overlying of the profiles (soil) is less than $30 \%$ which gradually increases from saprolite to soil. Therefore, the Fig. 13 shows that the areal coverage (in \%) of larger materials (cobbles, gravels coarse sand) is more in the 


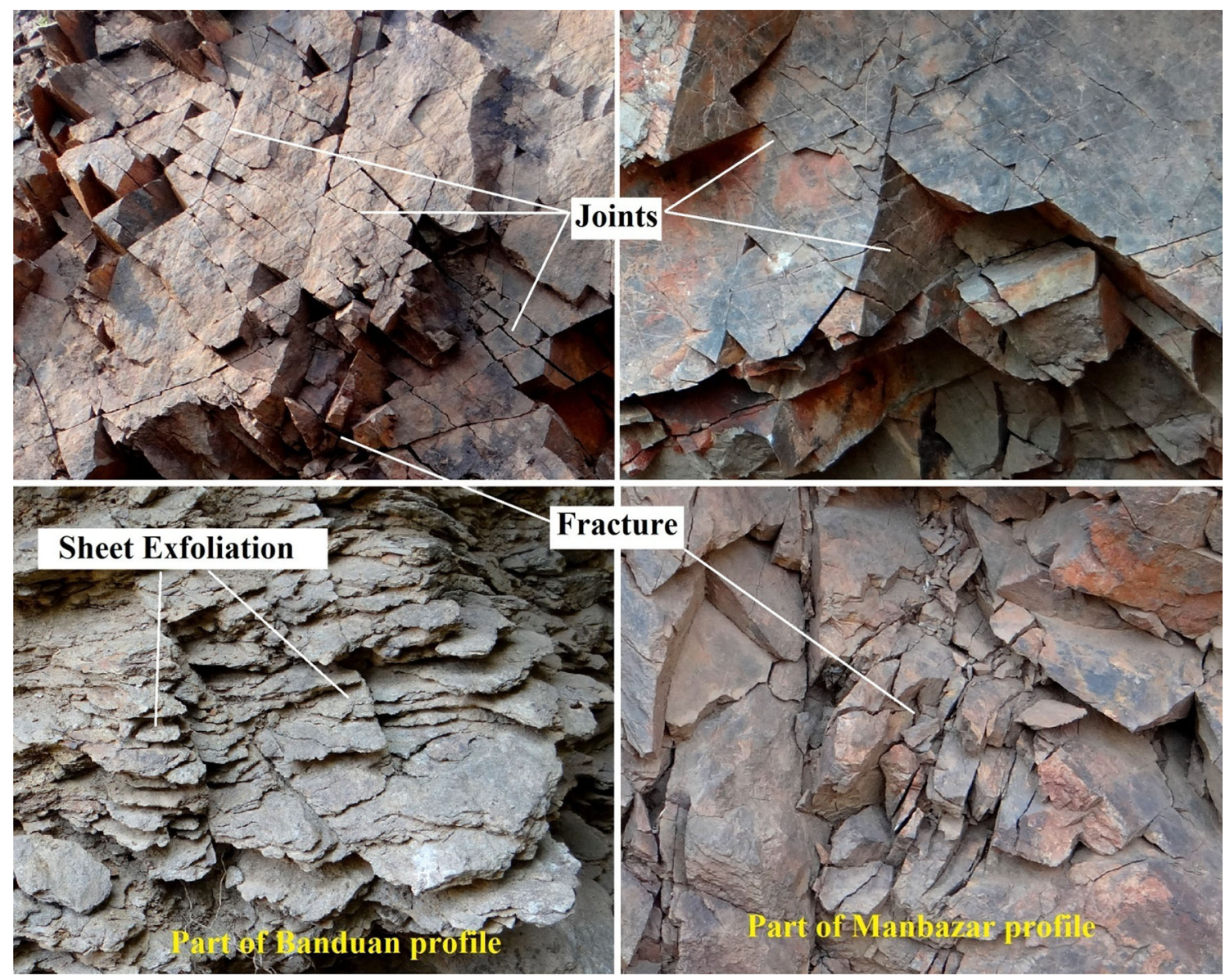

Fig. 10 Parent rock desintigration by physical weathering in the study area

primary stage of weathering where, coverage of finner materials in regolith and soil gradually increase with progressive stages of weathering.

Although, the GRADISTAT is tremendously elastic in terms of input and output (Blott and Pye 2001), it is still important for understanding the nature of physical disintegration process across the weathering profiles. Folk and Ward method in GRADISTAT program shows that the mean of the particle size is gradually reduces from saprolite to soil for all the profiles. In Manbazar-I and Banduan sample profiles mean size of materials belongs to the fine gravel grade which gradually reduces from very fine gravel and coarse sand in regolith and soil, respectively (Table 4 ). The sorting analysis shows that, in the initial stage of weathering (saprolite) the materials are poorly sorted than in soil or regolith (very poorly sorted). This can be argued that dominance of physical disintegration during initial stage of weathering instrumental for size sorting of materials as physical weathering produced large quantity of larger materials at the weathering front. But in the overlying layers further physical alteration and chemical decomposition of fragmented parent materials may cause production and mixing of sand, silt and clay (Fig. 9). In the most cases samples are negatively very fine skewed in all layers of the profiles where extremely leptokurtic in the saprolite and very leptokurtic or mesokurtic in the upper layer of the profiles (Fig. 14). Therefore, the kurtosis of the samples shows that most of materials are concentrated in same size (gravels) as extremely leptokurtic condition in the lower layer of weathering crust but increasing physical weathering, variation in materials size are found to distributed (mesokurtic nature) towards upper crust of the profiles. The percentage of gravels materials is mostly concentrated in the saprolite which gradually reduced from regolith to soil. But percentage of sand, silt and clay are predominantly less in saprolite which gradually increases towards soil in upper layer of the profiles. Therefore, the relationships between sand or silt and clay with gravel is inversely proportional but the relationship between sand, silt and clay is positive (Fig. 15) in all samples. So, in the study area physical disintegration and alteration of physical properties of parent rocks are predominantly occurred across the profiles. 
Fig. 11 Characteristics of X-ray diffraction diagram for mineral identification in different weathering class. The site location are a Manbazar-I; b Manbazar-II and c Banduan. In XRD graph Mon montmorillonite, $A l b$ albite,

Qua quartz, Mus muscovite, Bio biotite, Alu alumina, Sap saponite and Ilt illite
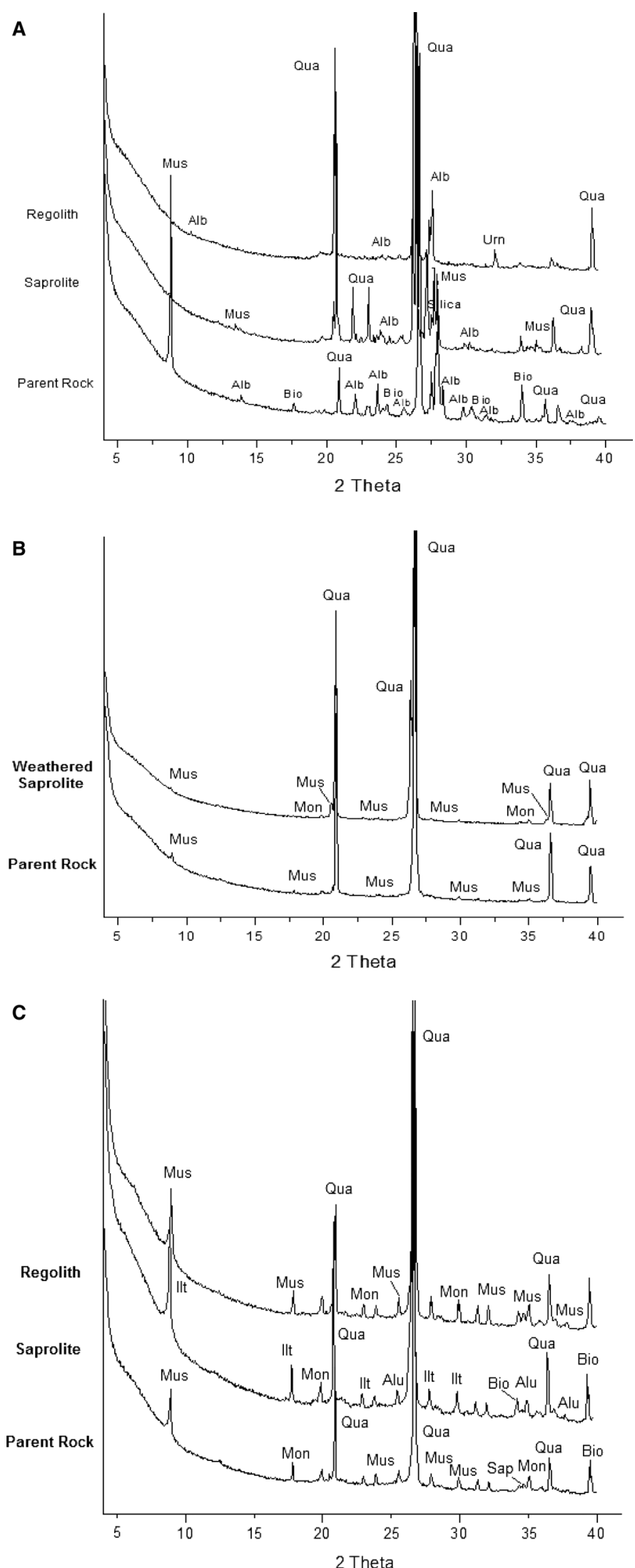

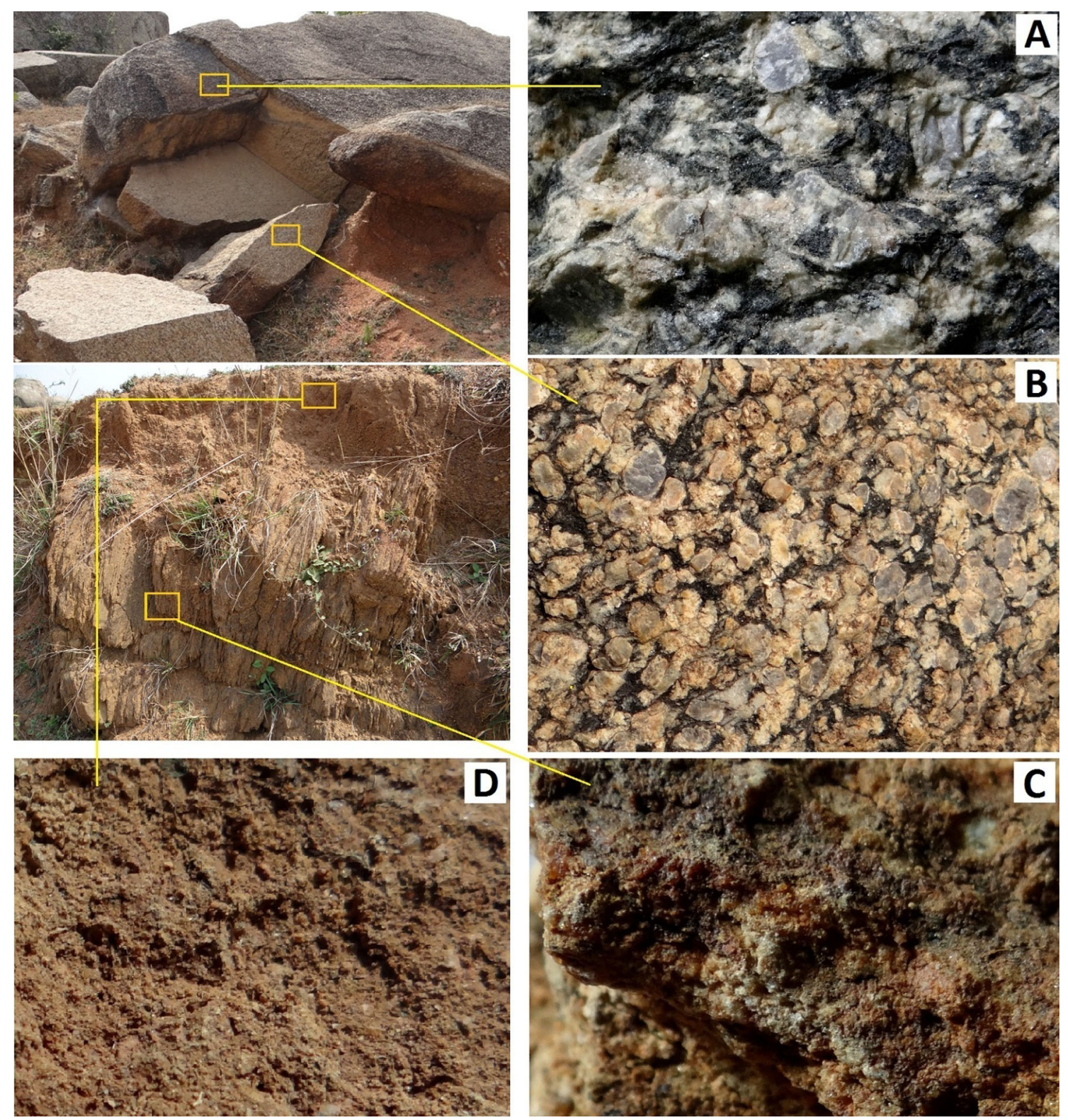

Fig. 12 Minerological changes troughtout the weathered crust (Manbazar-I). a Parent rocks (granite), b Primary weathered granite (initial alteration of primary minerals), $\mathbf{c}$ depply weathered saprolite, $\mathbf{d}$ soil with secondary clay minerals

Polarizing microscopic analysis of thin sections indicates quite clearly that mechanical weathering, rather than chemical weathering is primarily dominant in the granitic weathered profiles of the study area. All images from thin sections indicate preferential fracturing of most of the primary minerals in the granitic rocks. In some cases quartz exhibits considerably resistance to chemical weathering (Fig. 11c-e) where in Fig. 11a shows that quartz is physically fractured to form smaller quartz particles. Most of the images (Fig. 11b-e) show strong etching and fracture along surface and boundaries of the minerals (preferably feldspar, muscovite and biotite) as well as along the cleavage of fracture plane. Mainly plagioclase feldspar, muscovite and biotite shows clear evidence of fracturing and physical disintegration at the early stage of alteration (Fig. 11a-d). In few cases (Fig. 11d, e), feldspar and muscovite altered to secondary clay minerals (Harris and Adams 1966) which is indicative of the extreme stage of weathering. The images (Fig. 11d, e) of thin section clearly show the deep fractures over the primary minerals which more than susceptible to break down into fragmented particles of smaller size contributing to saprolite.

Chemical weathering processes are favoured in the hot humid climatic condition as the rate of chemical reactions 

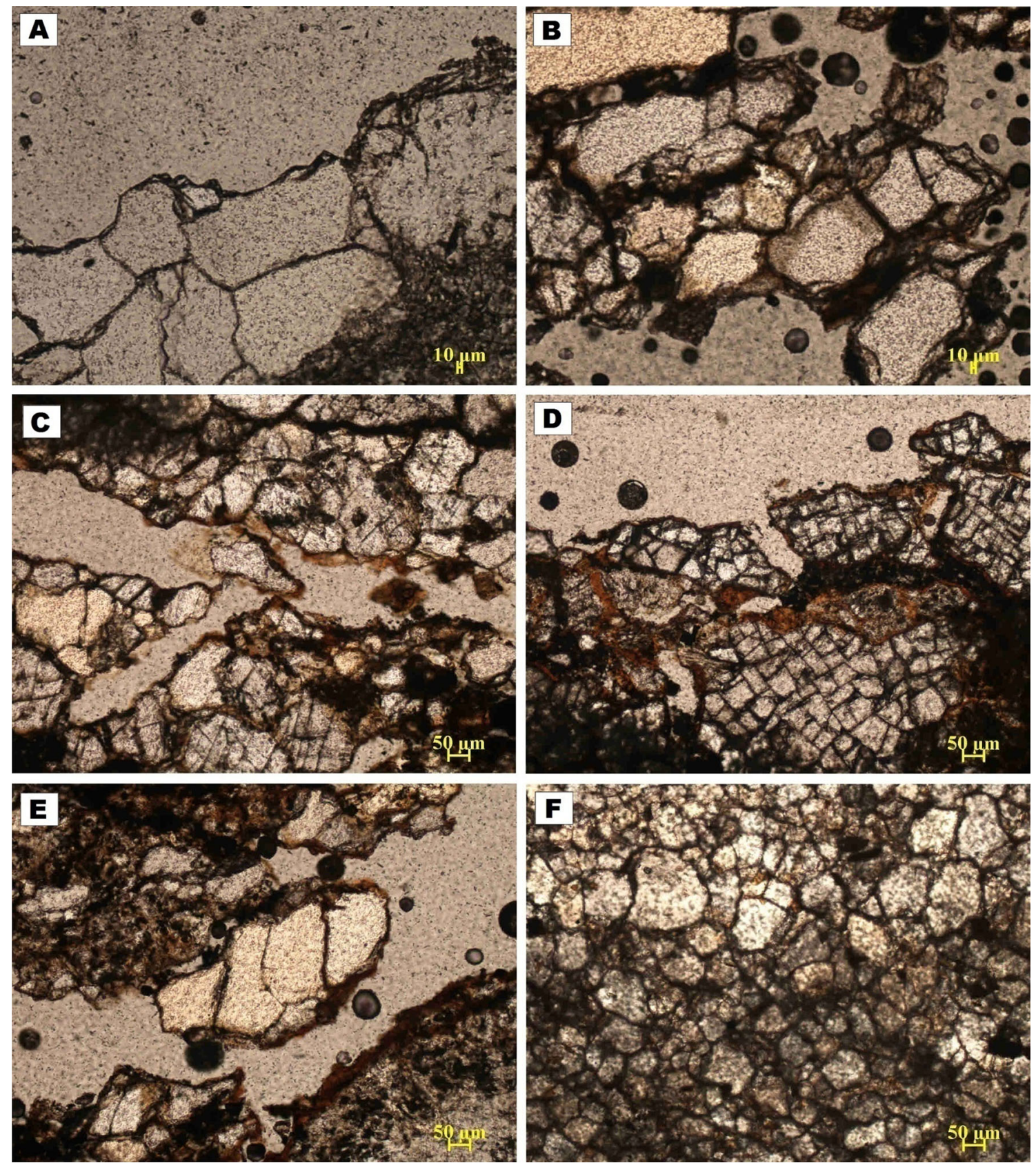

Fig. 13 a Thin section analysis by polarizing microscope showing the fractures causes physical disintegration of granitic parent rock from Manbazar-I profile; b Photo shows a minerals assemblage consist of quartz, feldspar and muscovite. All shows a degree of fracturing of parent rock and formed smaller fragmented particles.

increases with temperature. As the granitic rocks are exposed near surface, water enters the rock along joints and fractures, dissolving and oxidizing the silicates minerals presents in the rocks (Brantley 2010). So, fragmentation of rock and chemical alteration take place complementarily and simultaneously for soil formation. The results from the X-ray diffraction analysis reveal that

Photos $\mathbf{c}$ and e shows that most of the minerals are fractured accept quartz for its susceptibility to weathering; f Thin section showing effects of physical weathering on granitic rocks from Manbazar-II with strong etching along fracture planes to generate smaller fragmented particles

primary minerals of parent rocks such as feldspar, biotite and muscovite are chemically altered to secondary clay minerals such as montmorillonite, kaolinite and illite present in the regolith and soil. Table 5 shows that quartz is the most abundant minerals than feldspar and muscovite for its less susceptibility to weathering throughout the all studied profiles. In quartz's structure the degree of 
Fig. 14 Scatter diagrams showing the relationship between percentage of gravel, sand and finer materials from particle size distribution analysis
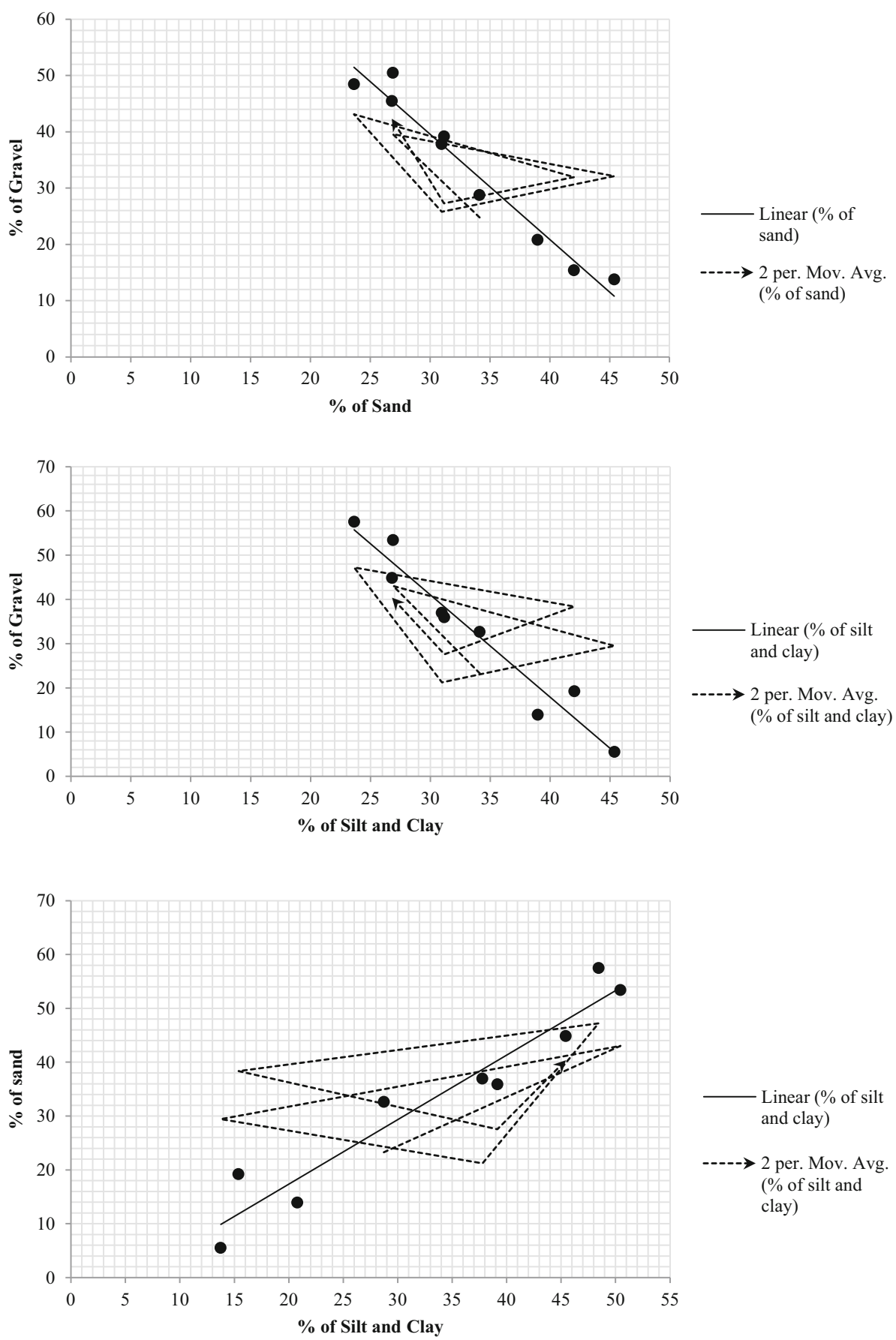

susceptibility is determine by its number and weakness of the cation links $\left(\mathrm{K}^{+}, \mathrm{Na}^{+}, \mathrm{Mg}^{2+}, \mathrm{Ca}^{2+}, \mathrm{Fe}^{2+}, \mathrm{Fe}^{3+}, \mathrm{Al}^{3+}\right)$ between the silicate tetrahedral which is completely interlocked and because of this quartz became more stable mineral (Chorley et al. 1984). After quartz, muscovite is more abundant mineral than feldspar and biotite which are primarily altered mainly to montmorillonite and kaolinite, and sometimes illite and smectite also. According to Chorley et al. (1984), the silicon tetrahedral structure is tight enough for orthoclase feldspars (microcline) but in plagioclase feldspars (albite) this structure is week causing replacement of $\mathrm{Si}^{4+}$ ions by $\mathrm{Al}^{3+}$ ions. Therefore, orthoclase feldspars are present in the soil as primarily altered minerals but plagioclase feldspars (albite) are changed to secondary clay (Table 5). From muscovite

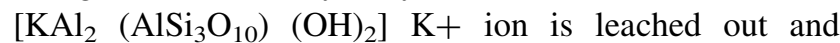
transformed to secondary clay (kaolinite). But in case of biotite the tetrahedral structure is sandwiched between $\mathrm{Mg}^{2+}, \mathrm{Fe}^{2+}, \mathrm{Al}^{3+}$ and $\mathrm{K}^{+}$ions (Chorley et al. 1984) which is the cause of release of biotite in saprolite and therefore, 
Particle size distribution in \%
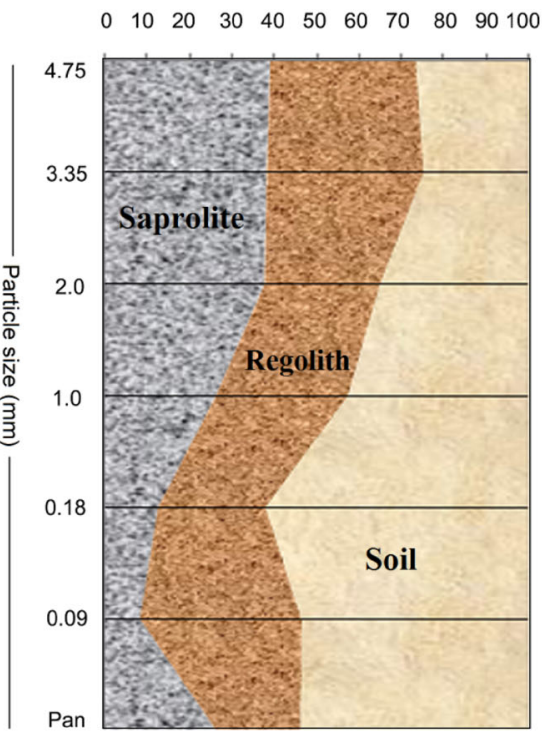

Manbazar - I
Particle size distribution in \%
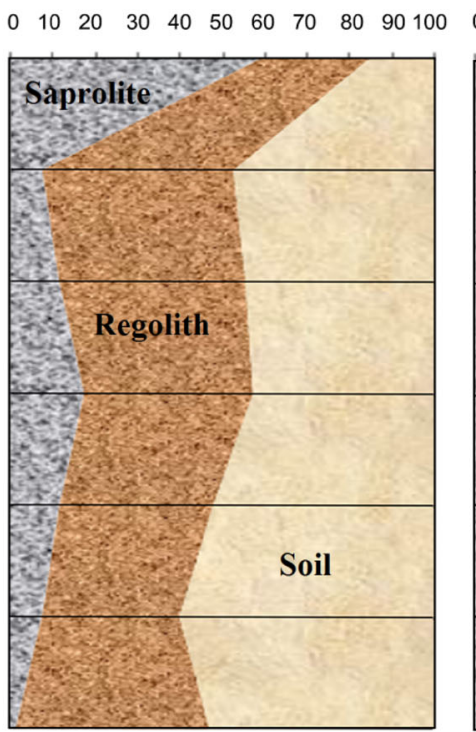

Manbazar - II
Particle size distribution in \%
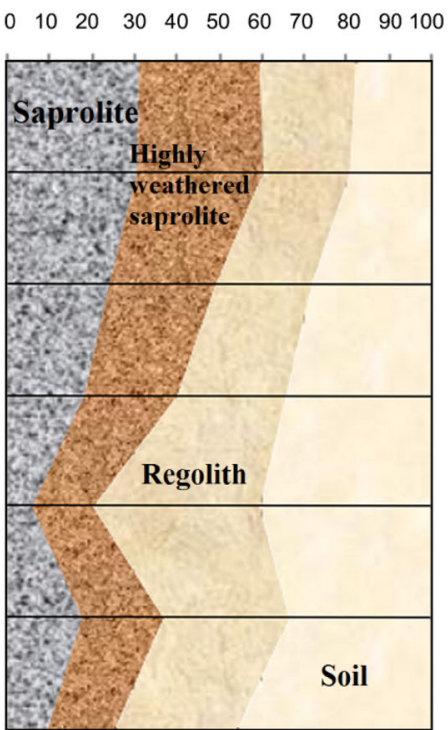

Banduan

Fig. 15 Changing distribution of particle size in different weathering classes

Fig. 16 Two-cycle concept of soil clay genesis (after Matsui 1966)

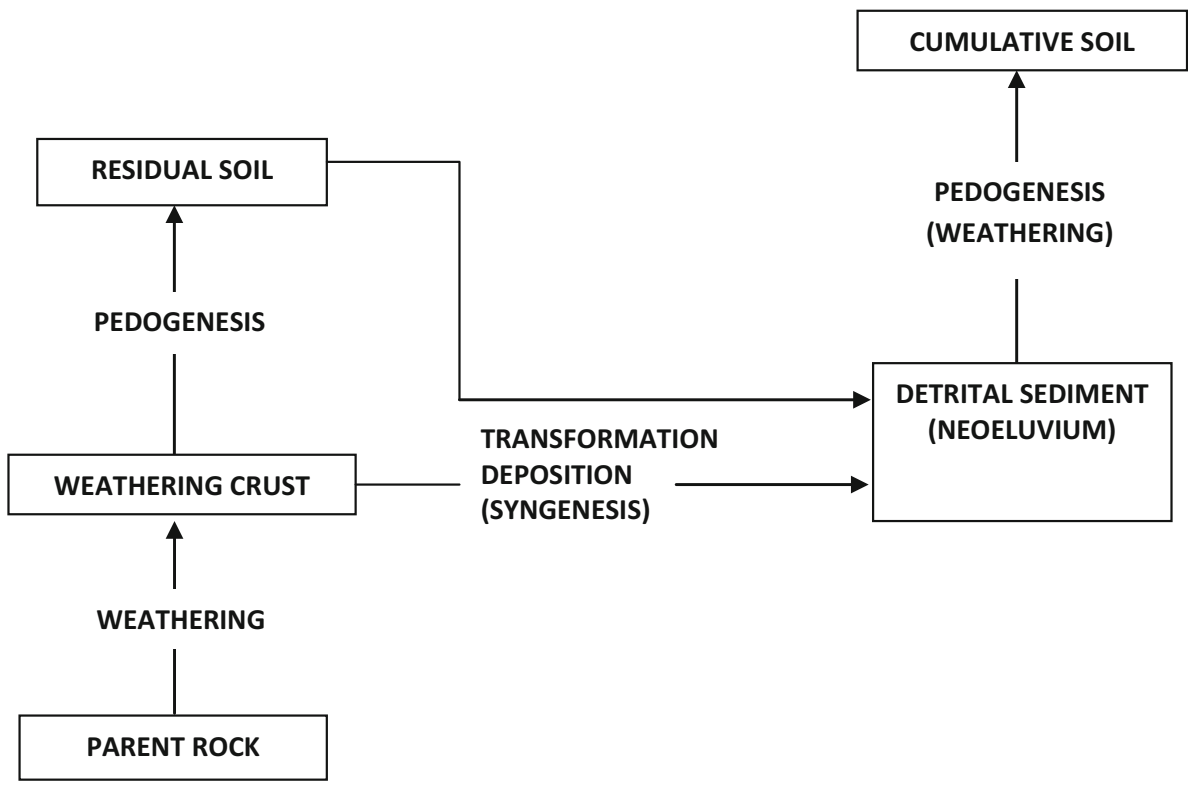

its chemically altered to secondary clay mineral. In some cases formation of these clay minerals might be different in the weathering profile in a pedogenic environment. Some basic pedological process like podzolization, monosiallitisation, allitisation etc. are the principal types of chemical weathering to generate secondary clay form primary minerals (Pedro 1983). Figure 16 is the two-cycle concept of genesis of soil clay minerals suggested by Matsui (1966). It shows some possible pathways for secondary clay formation during intense weathering and pedogenesis processes. The presence of montmorillonite, kaolinite and illite in the overlying portion of weathered crust indicates an advance chemical weathering stage. But the abundance of montmorillonite (phylosilicates mineral) rather than kaolinite as revealed form XRD analysis signifies an early weathering stage and also indicates potentialities of these minerals for further chemical alteration to develop a mature soil with progressive enrichment of clay minerals. On the other hand, occurrences of feldspar, muscovite and biotite (Table 6) throughout the profiles are indicative of a primary stage of alteration with a considerable potentiality for further chemical weathering. 
Table 6 Summary of particle size analysis showing percentage of gravel, sand and finer materials

\begin{tabular}{|c|c|c|c|c|c|c|c|}
\hline Pro & $\begin{array}{l}\text { Weathering } \\
\text { class }\end{array}$ & $\begin{array}{l}\text { Mass of gravel retained } \\
\text { from sieve }(\mathrm{gm})\end{array}$ & $\begin{array}{l}\% \text { of } \\
\text { gravel }\end{array}$ & $\begin{array}{l}\text { Mass of sand retained } \\
\text { from sieve }(\mathrm{gm})\end{array}$ & $\begin{array}{l}\% \text { of } \\
\text { sand }\end{array}$ & $\begin{array}{l}\text { Mass of silt and clay retained } \\
\text { from sieve }(\mathrm{gm})\end{array}$ & $\begin{array}{l}\% \text { of silt } \\
\text { and clay }\end{array}$ \\
\hline \multirow[t]{3}{*}{ M-I } & Saprolite & 86.94 & 38.97 & 6.58 & 20.80 & 6.22 & 13.92 \\
\hline & Regolith & 76.13 & 34.13 & 9.09 & 28.74 & 14.59 & 32.65 \\
\hline & Soil & 59.99 & 26.89 & 15.96 & 50.46 & 23.87 & 53.42 \\
\hline \multirow[t]{3}{*}{ M-II } & Saprolite & 87.11 & 45.38 & 11.31 & 13.75 & 1.4 & 5.53 \\
\hline & Regolith & 59.44 & 30.97 & 31.08 & 37.79 & 9.36 & 36.95 \\
\hline & Soil & 45.39 & 23.65 & 39.85 & 48.45 & 14.57 & 57.52 \\
\hline \multirow[t]{3}{*}{ BAN } & Saprolite & 80.93 & 42.03 & 6.5 & 15.39 & 12.44 & 19.21 \\
\hline & Regolith & 60.02 & 31.17 & 16.54 & 39.17 & 23.26 & 35.92 \\
\hline & Soil & 51.61 & 26.80 & 19.19 & 45.44 & 29.05 & 44.86 \\
\hline
\end{tabular}

\section{Conclusion}

The present study confirms that the parent rocks are initially disintegrated by the physical weathering processes to produced materials that become available for further alteration by chemical weathering processes. The rock particles while undergoing these processes will gradually reduce in size to produce finer soil particles and their abundance increases upwards as the upper layers are more exposed to aerial processes. Primary minerals of the parent rocks are chemically altered into secondary clay minerals in the existent weathering crust. The reducing nature of grain size throughout the profiles indicates the geophysical alteration of hard and large materials (cobbles and gravels) to softy finer materials (silt and clay) where mineralogical changes of those rock materials also take place simultaneously. The sub-tropical hot humid climate of the study area is responsible for an intensive weathering that results in a large scale alteration of primary alluminosilicate minerals of granitoid rocks to secondary clay minerals under sufficient rain water supply. Alteration of primary minerals into secondary minerals of the weathering front along the edges of mineral crystal leads to weathering of the crystal structure and its breakdown consequently. Thus, weathering profile is the outcome of combination of processes like disintegration (as physical processes) along the micro-cracks, fractures, joints of the bed rock and hydrolysis, dissolution, oxidation (as chemical processes) along with recognition of produce materials through erosion, transportation and re-deposition within the profile.

Kaolinite is expected to be the dominant clay mineral in a granitic weathering profile under humid tropical to subtropical condition, but in the studied profiles, presence of primarily altered feldspar and muscovite and abundance of montmorillonite rather than kaolinite indicate that the system is at an early stage of chemical weathering. On the other hand well shorted and leptokurtic distribution of large size materials within most of the studied profiles signify dominance of large rock fragments which are liable to further disintegration and chemical decomposing to be reduce to silt and clay. So, abundance of physically altered primary minerals and presence of secondary clay minerals produce through slight modification of the primary minerals confirm that the weathering has not progressed remarkably along the pathways of alterations and the particles are yet to reach and equilibrium trough further weathering and chemical alterations.

Acknowledgments Authors are thankful to the Department of Geography and Environment Management, Vidyasagar University for physical analysis of samples. The Department of Chemistry, IIT Kharagpur helps to mineralogical analysis of the samples. Authors are thankful to Dr. K. L. Pruseth, Department of Geology and Geophysics, IIT Kharagpur, for kind helps in petrographic analysis and also thankful to Tapas Mallik for helping field study.

\section{References}

Apollaro C, Marini L, De Rosa R, Settembrino P, Scarciglia F, Vecchio G (2007) Geochemical features of rocks, stream sediments, and soils of the Fiume Grande Valley (Calabria, Italy). Environ Geol 52:719-729

Anand RR, Gilkes RJ (1984a) Weathering of ilmenite in a lateritic pallid zone. Clays Clay Miner 32(5):363-374

Anand RR, Gilkes RJ (1984b) Weathering of hornblende, plagioclase and chlorite in meta-dolerite, Australia. Geoderma 34(3, 4):261-280

Anand RR, Paine M (2002) Regolith geology of the Yilgarn Craton, Western Australia: implications for exploration. Aust J Earth Sci 49(1):3-162

Atkinson D (2004) Weathering, slopes and landforms. Hodder \& Stoughton, London, pp 55-78

Banfield JF, Eggleton RA (1988) Transmission electron microscope study of biotite weathering. Clays Clay Miner 36:47-60

Berg G (1932) Das Vorkommen der chemischen Elemente auf der Erde. JA Barth, Leipzig, p 113

Blott SJ, Pye K (2001) GRADISTAT: a grain size distribution and statistics package for the analysis of unconsolidated sediments. Earth Surf Proc Land 26:1237-1248 
Borrelli L, Perri F, Critelli S, Gullà G (2012) Minero-petrographical features of weathering profiles in Calabria, southern Italy. Catena 92:196-207

Borrelli L, Perri F, Critelli S, Gullà G (2014) Characterization of granitoid and gneissic weathering profiles of the Mucone River basin (Calabria, southern Italy). Catena 113:325-340

Bouchard S, Jolicoeur M (2000) Chemical weathering studies in relation to geomorphological research in southeastern Canada. Geomorphology 32:225-238

Brantley SL (2010) Weathering: rock to regolith. Nat Geosci 3(5):305-306

Buccianti A, Apollaro C, Bloise A, De Rosa R, Falcone G, Scarciglia F, Tallarico A, Vecchio G (2009) Natural radioactivity levels (K, Th, $\mathrm{U}$ and $\mathrm{Rn}$ ) in the Cecita Lake area (Sila Massif, Calabria, Southern Italy): an attempt to discover correlations with soil features on a statistical base. Geoderma 152:145-156

Bui EN, Mazullo J, Wilding LP (1990) Using quartz grain size and shape analysis to distinguish between aeolian and fluvial deposits in the Dallol Bosso of Niger (West Africa). Earth Surf Proc Land 14:157-166

Calcaterra D, Bruno D, Parise M, Silvestri F, Critelli S, Capparelli G (2004) Effects of weathering on slope instability in gneissic rocks at Luzzi (Calabria, Italy). Landslides, A.A. Balkema Publ. 2:1233-1239

Caracciolo L, Tolosana-Delgado R, Le Pera E, Von Eynatten H, Arribas J, Tarquini S (2012) Influence of granitoid textural parameters on sediment composition: implications for sediment generation. Sediment Geol 280:93-107

Chiu CF, Ng WWC (2014) Relationships between chemical weathering indices and physical and mechanical properties of decomposed granite. Eng Geol 179:76-89

Chorley RJ, Schumm SA, Sugden DE (1984) Geomorphology. Methuen and Co. Ltd., Landon, pp 203-224

Dolui G, Chatterjee S, Das CN (2014) Weathering and minerological alteration of granitic rocks in southern Purulia District, West Bengal, India. Int Res J Earth Sci 2(4):1-12

Dunn JA, Dey AK (1942) The geology and petrology of eastern Singhbhum and surrounding areas. Geol Surv India Mem 69(2):281-456

Ehlmann AJ (1968) Clay mineralogy of weathered products and river sediments. J Sedim Petrol 2:885-894

Eswaran H, Bin WC (1978a) A study of a deep weathering profile on granite in Peninsular Malaysia. II. Mineralogy of the clay, silt, and sand fractions. Soil Sci Soc Am J 42:149-153

Eswaran H, Bin WC (1978b) A study of a deep weathering profile on granite in Peninsular Malaysia. III. Alteration of Feldspars. Soil Sci Soc Am J 42:154-158

Eswaran H, Heng YY (1976) The weathering of biotite in a profile on gneiss in Malaysia. Geoderma 16(1):9-20

Folk RL (1954) The distinction between grain size and mineral composition in sedimentary-rock nomenclature. J Geol 62:344-359

Folk RL, Ward WC (1957) Brazos River bar: a study in the significance of grain size parameters. J Sediment Petrol 27:3-26

Friedman GM (1979) Differences in size distributions of populations of particles among sands of various origins. Sedimentology 26:3-32

Friedman GM, Johnson KG (1982) Exercises in sedimentology. Wiley, New York

Gerrard AJ (1988) Rocks and landforms. Unwin Hyman Ltd., London, pp 107-167

Gilkes RJ, Scholz G, Dimmock GM (1973) Lateritic deep weathering of granite. J Soil Sci 24(4):523-536

Gullà G, Matano F (1997) Surveys of weathering profile on gneiss cutslopes in Northern Calabria, Italy. In: IAEG sponsored international symposium on Engineering geology and the environment. AA Balkema Publishers, vol 1, pp 133-138

Harris RC, Adams JAS (1966) Geochemical and mineralogical studies on the weathering of granitic rocks. Am J Sci 264:146-173

Helgeson HC (1968) Evaluation of irreversible reactions in geochemical processes involving minerals and aqueous solution. I. Thermodynamic relations. Geochim Cosmochim Acta 32:853-877

Islam MR, Stuart R, Risto A, Vesa P (2002) Mineralogical changes during intense chemical weathering of sedimentary rocks in Bangladesh. J Asian Earth Sci 20:889-901

Le Pera E, Sorriso-Valvo M (2000) Weathering and morphogenesis in a mediterranean climate, Calabria, Italy. Geomorphology 34:251-270

Le Pera E, Critelli S, Sorriso-Valvo M (2000) Weathering of gneiss in Calabria, southern Italy. Catena 42:1-15

Matsui T (1966) A two-cycle concept on the genesis of soil clay material. Clay Sci (Nendo Kagaku, J Clay Sci Soc Jpn) 5:2-13

Mondensi MC (1983) Weathering and morphogenesis in a tropical plateau. Catena 10(3):237-251

Novikoff A, Tawlassou G, Gac JY, Bourgeat F, Tardy Y (1972) Alteration des biotites dans les arenes des pays temperes, tropicaux et equatoriaux. Sci Geol 25:287-305

Paven MJ, Fedoroff N, Robert M (1981) Alteration meteorique des biotites on Algerie. Geoderma 26:287-309

Pedro G (1983) Structuring of some basic pedological processes. Geoderma 31:289-299

Perri F, Scarciglia F, Apollaro C, Marini L (2015) Characterization of granitoid profiles in the Sila Massif (Calabria, southern Italy) and reconstruction of weathering processes by mineralogy, chemistry, and reaction path modelling. J Soils Sediments 15(6): 1351-1372

Pope GA, Dorn RI, Dixon JC (1995) A new conceptual model for understanding geographical variations in weathering. Ann Assoc Am Geogr 85:35-64

Scarciglia F, Le Pera E, Critelli S (2005) Weathering and pedogenesis in the Sila Grande Massif (Calabria, South Italy): from field scale to micromorphology. Catena 61:1-29

Scarciglia F, Le Pera E, Critelli S (2007) The onset of the sedimentary cycle in a mid-latitude upland environment: weathering, pedogenesis, and geomorphic processes on plutonic rocks (Sila Massif, Calabria). In: Arribas J, Critelli S, Johnsson M (eds) Sedimentary provenance and petrogenesis: perspectives from petrography and geochemistry. Geological Society of America, Special Paper 420:49-166

Scarciglia F, Saporito N, La Russa MF, Le Pera E, Macchione M, Puntillo D, Crisci GM, Pezzino A (2012) Role of lichens in weathering of granodiorite in the Sila uplands (Calabria, southern Italy). Sediment Geol 280:119-134

Singh B, Gilkes RJ (1991) Phosphorus sorption in relation to soil properties for the major soil types of south-western Australia. Soil Res 29(5):603-618

Soil Survey Staff (1975) Soil Taxonomy: a basic system of soil classification for making and interpreting soil surveys. U.S.D.A. Soil Conservation Service, Agri. Handbook No. 436:754

Steinmann P, Lichtner PC, Shotyk W (1994) Reaction path approach to mineral weathering reactions. Clay Clay Miner 42(2):197-206

Turkington AV, Philips JD, Champbell SW (2005) Weathering and landscape evolution. Geomorphology 67:1-6

Wilson MJ (1975) Chemical weathering of some primary rockforming minerals. Soil Sci 119(5):349-355

Wilson MJ (2004) Weathering of the primary rock-forming minerals: processes, products and rates. Clay Miner 39(3):233-266

Yong RN, Warkentin BP (1966) Introduction to soil behaviour. Macmillan, New York 